\title{
New sedimentary and geomorphic evidence of tsunami flooding related to an older events along the Tangier-Asilah coastal plain, Morocco
}

Hajar El Talibi ${ }^{1 *}$, Said El Moussaoui ${ }^{1}$, Mohamed Najib Zaghloul ${ }^{1}$, Khadija Aboumaria', Patrick Wassmer ${ }^{2,3}$ and Jean Luc Mercier ${ }^{3}$

\begin{abstract}
Background: Despite a position along the passive margin of Africa, the Moroccan Atlantic coast is under the influence of the tsunami threat from earthquakes triggered along the Nubia-Eurasia plate boundary. Along Tangier, Asilah, Sale and Mazagao's coasts, tsunami have been described since historic times. The 1755 Lisbon quake triggered a tsunami that struck the shores of Morocco $60 \mathrm{~min}$ after the tremor, the waves reaching from 2 to $15 \mathrm{~m}$ in amplitude. The coastal sedimentary record, together with other proxies, is now being experienced to discriminate and reconstruct evidence of prehistoric inundation events.

Results: Recently, we investigated the southwestern coast of Tangier (Tahaddart estuary) and found out morphologies and sedimentary deposits evidencing a strong energy-flooding event. A combination of sedimentological (grain size, sorting, AMS) and microplaentological analyses combine to provide a primary reconstruction of uprush and backwash phases of tsunami deposition and flow dynamics. This event that we attribute to the 1755 tsunami, left noticeable traces on a hilly dissected topography. In the proximal domain, no deposits were emplaced. The high turbulence of the flow allows a complete erosion of the soil. Landward, the decreasing of the energy induced a strong depositional process. The thick brownish sandy layer deposited contains at the base large angular rip-up clasts of dark soil. Marine origin of the deposits is attested by bioclasts and the presence of benthic and planctonic foraminifera. In the distal domain, the sudden loss of energy, due i) to a reverse slope, and to ii) a flow diffluence resulting from the presence of a pass between two dunes, resulted in an accumulation of a huge amount of unsorted marine bioclasts, rounded pebbles, sub-angular beach rock clasts, remains of microlithic industry, and pieces of pottery displaying blunt breaks. Reaching the proximal dune, beyond an undulating line, still perceptible in the landscape, the flow energy was insufficient to erode the soil, which remained unaffected. Application of the AMS technique to the sediments confirmed that the lower part of the deposits was emplaced by a landward flow spreading $N 91^{\circ}-171^{\circ}$ (uprush phase to the SE) while the upper part was

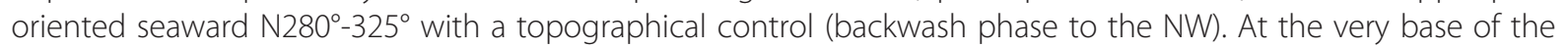
deposit, the first AMS measure gives an uprush direction of $\mathrm{N} 105^{\circ}$.

(Continued on next page)
\end{abstract}

\footnotetext{
* Correspondence: eltalibi.hajar-etu@uae.ac.ma

'Department of Earth Sciences Faculty of Sciences and Techniques,

University Abdelmalek Essaadi, PB. 416, 90000 Tangier, Morocco

Full list of author information is available at the end of the article
} 
(Continued from previous page)

Conclusion: This study concluded that sedimentary and geomorphic insights plead for occurrence of a strong energy marine flooding on the coast South of Tangier in the area of Tahaddart. This high energy flooding that might be consistent with the waves depth provided by the 1755 archives. The height of the dunes affected by wave erosion processes allow to estimate wave heights around 6-8 meters.

Keywords: Tsunami sedimentary signature, Grain size, Anisotropy of magnetic susceptibility, Foraminifera, Tangier, Morocco

\section{Background}

Morocco sits aside the boundary between the African and Eurasian plates. This tectonic setting provides a wide range of potential tsunamigenic sources (El Alami and Tinti 1991; Cherkaoui and El Hassani 2012). Therefore, it is one of the most tectonically active zone in the region that has historically experienced a number of large earthquakes induced tsunamis along:

i) The dextral transform zone of the Azores-Gibraltar (Gulf of Cadiz), which is at the origin of large historical earthquakes (Baptista et al. 1998; El Alami and Tinti 1991), particularly the 1755 November $1^{\text {st }}(\mathrm{Mb}$ 8.5 to 9) (Gutscher et al. 2006). This area is still active, as evidenced by the earthquake of 28 February 1969 (Mb 7.9) and 12 February 2007 (Mb 6.3), also felt in Morocco (Fig. 1).

ii) The seismic zone Alboran-Betic, East of Gibraltar Strait (Alvarez-Gómez et al. 2011), source of a tsunamigenic earthquakes with magnitude more or less important, including 881, 1522, 1680, 1856 and 1980 (Kaabouben et al. 2009). The most recent tsunami from this region is associated with the earthquake Zemmouri-Boumerdes (Algeria) in 2003, recorded in many parts of the western Mediterranean, on the Algerian coast and the Balearic Islands (Sahal et al. 2009; Paris et al. 2010).

Another extreme scenarios would be a collapse of La Cumbre Vieja volcano on the Island of La Palma in the Canary Islands, and the release of a volume of $375 \mathrm{~km}^{3}$ simultaneously (Harbitz et al., 2012). In this eventuality, the tsunami could reach the Moroccan coast within 1 h30 (Ward and Day 2001).

An historical tsunami database for Moroccan has been compiled by several researchers (El Mrabet 2005; Kaabouben et al. 2009; Baptista and Miranda 2009; Blanc 2008; 2009). This database now has a record of over several historic events. The two largest of these events occurred in February 1969, and in November 1755; this latter is the oldest historically well documented tsunami in Gulf of Cadiz. Others earthquakes more questionable such as 382, 881, 1761, 1941, and 1975 AD earthquakes are also suggested (Kaabouben et al. 2009).
Cataloguing and assessing tsunami records are important for long-term tsunami prediction and for tsunamihazard mapping. In the case of Tangier-Asilah, however, as well as for a number of other Moroccan coastlines prone to tsunami-hazard; historical time series of tsunamis are too short to develop a predictive chronology for events using only documented historic archives. The way to obtain long-term data is to study palaeotsunamis, i.e., to identify, map, date and decipher prehistoric tsunami deposits. These deposits also provide a proxy record for large earthquakes.

The 2004 Indian Ocean tsunami marks the beginning of an increasing interest of the scientific community for palaeo-tsunami recordings along seashore and the number of contributions that followed the 2011 Tohoku-Oki tsunami show that this interest never run out (Chagué-Goff et al. 2012a). The sedimentary records of past high energy events is becoming more and more well studied worldwide, and scientists now have access to a more accurate proxies toolkit, including sedimentological, micropalaeontological, geochronological, geophysical, and mineralogical methods (Dawson and Stewart 2007; Bourgeois 2009; Wassmer et al. 2010; Chagué-Goff 2010; Keating et al. 2011a; Jagodziński et al. 2012; Goff et al. 2012; ChaguéGoff et al. 2012b). In the vicinity of Moroccan coasts, evidence of strong modern and pre-historic earthquakes and tsunamis has been found and studied in Spain, Portugal (e.g. Kortekaas and Dawson 2007; Rodríguez-Vidal et al. 2011; Costa et al. 2012; Cuven et al. 2013).

Despite the important impact of the tsunami on the African coasts, there has been no systematic studies and clear sedimentological deposits evidenced until recently. Studies of tsunami began with El Alami and Tinti (1991); Baptista et al. (1992); Blanc (2008; 2009); Kaabouben et al. (2009); Omira et al. (2012). Researchers focused studies along the coast between Tangier-El Jadida (Mhammdi et al. 2008; Omira et al. 2009; Omira et al., 2010; Medina et al., 2010; Omira et al., 2013). Tens of cores have been done in the lagoons around El Jadida and in the area of Tangier and recent tsunami deposit that could be related to the 1755 event has been identified (Mellas et al. 2012). Moreover, an older deposit ( $>4850 \mathrm{BP}$ ) has been evidenced in Tangier, intercalated within lagoons and mud deposit 


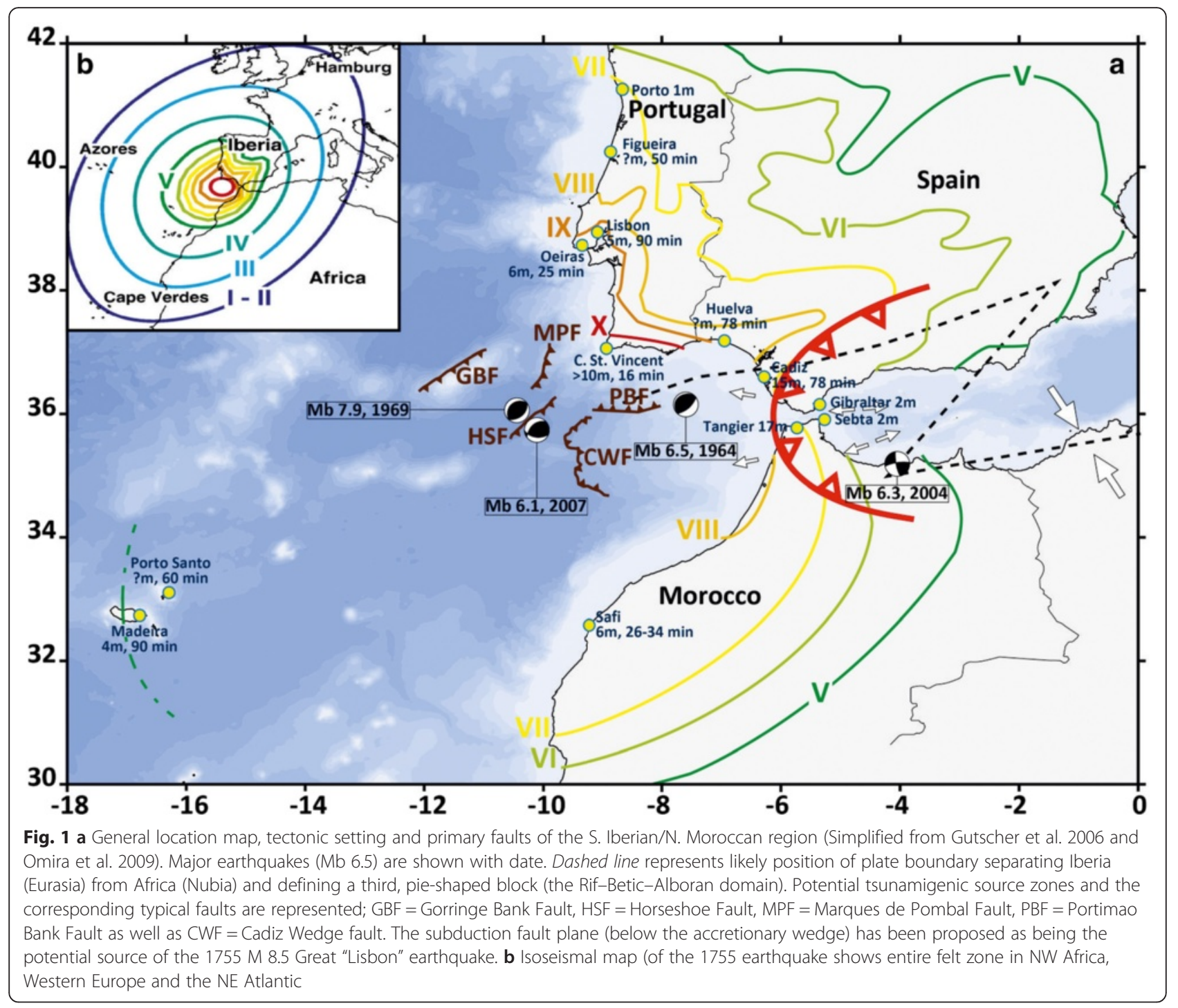

(Genet 2011; Mellas et al. 2012). In the Larache area, a recent work conducted by Mhammdi et al. (2015) described a marine valley filling approximatively dated between 5000 and 3000 B.P.

Between the two former area, the present study, was carried out along the Tangier-Asilah coastline. It is based on a fine investigation in which traditional methods of field work and sedimentology are coupled with magnetic proxies. It aims to identify new tsunamis deposits related to the so-called "1755 Lisbon tsunami" and to provide new insights on the characteristics of this event along the Atlantic Moroccan coasts. The deposits identified, have been deciphered and their characteristics used to establish flooding heights, extension of flooded areas and run-up.

\section{Regional effects and record of the AD 1755 tsunami}

The Lisbon earthquake and tsunami were the greatest natural catastrophe that affected Europe in recent history and their effects left a mark in the collective memory of the inhabitants of the Iberian coast (Rodríguez-Vidal et al. 2011). November $1^{\text {st }} 1755$, the city of Lisbon was destroyed by an earthquake of $\mathrm{Mb}$ 8.7 (Baptista et al. 2003; Gutscher et al. 2006) constituted by a sequence of three tremors. Ignited by the collapse of houses, numerous fires raged for a week (Blanc 2008). A tsunami surged on the coast $30 \mathrm{~min}$ after the quake, flooding the harbour and the lower city. Many other Portuguese coastal cities were also strongly affected. The effects of the tsunami were also described in remote areas of Spain and along the African Atlantic coast, as well as in Cornwall and in Scotland (Chambers 1757; Bewick 1757; Borlase 1755; Mendonça 1758). Eventually, Barkan et al. (2009) reported evidences of tele-tsunami impacts on the other side of the Atlantic, in Brazil, Caribbean and Canada. 
The Most damaging earthquakes and tsunamis that have affected the coasts of Portugal, Morocco and Spain were probably generated in the SWIT (SW Iberian Transpressive Domain) zone. Five typical faults have been identified within the SWIT zone (Omira et al. 2009). They are: the Gorringe Bank fault (GBF) (Johnston, 1996), the Marques de Pombal Fault (MPF) (Zitellini et al., 1999), the Horseshoe Fault (HSF) (Gràcia et al. 2003; Matias et al., 2005), the Portimao Bank Fault (PBF) (Baptista et al., 2003) and the Cadiz Wedge Fault (CWF) (Gutscher et al., 2002, Gutscher et al. 2006). Their locations are specified in Fig. 1.

\section{Geology and morphology of the Tangier Asilah coastline}

The coastal geomorphology of the study area is strongly influenced by its geology. The dominance of Quaternary formations, allowed the establishment of low coastal detritus accumulation (Durand-Delga and Komprobst 1985). The Quaternary structural control (Alouane 1986) of this sector resulted in the individualization of slightly raised areas corresponding to erosion platforms formed by biocalcarenites while subsident areas consist of marine Quaternary deposits. This is especially observed in the northern region between Charf el Ahab and Achakkar where Quaternary marine deposit are present as accumulation layers of conglomerates and sandy limestone formations covered with blocks and boulders connected to the continental Ouljien (Boughaba 1992). South Asilah, Cenozoic hills (Jaaidi et al. 1993) are composed by marl and Asilah sandstone. During the last glacial maximum (LGM), the landscape was slightly different, the river mouth were $120 \mathrm{~m}$ lower and at distance from the nowadays coast. East-West valley incised the tertiary deposits. Since the post LGM, a marine transgression and fluvial sediment filled-up the lower valleys; the model is a transgressive barrier island with two estuaries (Reinson 1992). During prehistoric times (Otte and Abdellaoui 2004; Bridoux et al. 2011), the regularization of the coast was not yet realized and pre-Roman and Roman population to install settlements and commercial harbor ( $\mathrm{Had}$ Gharbia, the Roman "Zilil Lulia Constantia") in this bay landscape. In the Scylax journey, $\mathrm{VI}^{\circ}$ century $\mathrm{BC}$ (Müller 1855), a bay named "Kôtes" is described between two cities Tangier and Lixus, Phoenician and Roman settlement, North of Asilah (Ruiz and Dietler 2009). Simultaneously development of agriculture and climatic change produces strong soil erosion which favoured the accumulation of fine sediments in the lower valley. Slowly, the north-south marine current led to the development of a pit bar and regularized the coast creating tidal flats; this current cut some Pliocene deposits in the North, then Pleistocene eolianites formations located along the sea shore including the Tahaddart and the Hachef rivers (Fig. 2b) giving the nowadays landscape (Alouane 1986). The beach is composed by a broad strand plain, limited by small dunes dissected by many washover channels, cut by tidal inlets and limited by some secondary tidal channels.
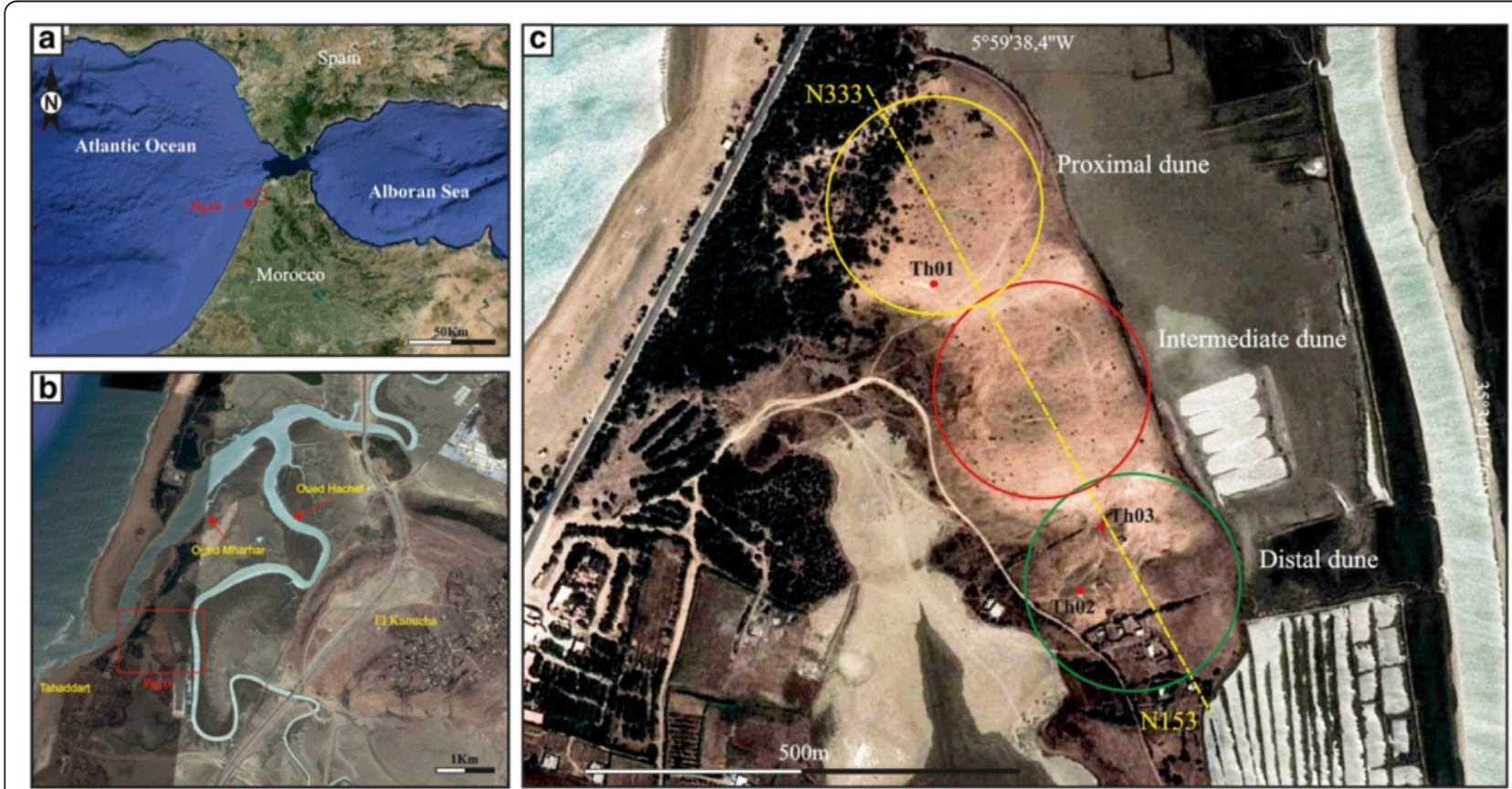

Fig. 2 a Geographical location of Moroccan north-east Atlantic coast. b Satellite view of the study area. c Satellite view of the Mharhar alluvial plain. The circles illustrate the three investigated dunes as well the studied outcrops (Th01, Th02 and Th03) 
Tahaddart estuary reached the Atlantic Ocean along sand dunes, formed on an offshore bar, oriented north south that protect the marshy area from sea water inundation (Jaaidi et al. 1993).

\section{5 tsunami along Moroccan coast}

The coastline, oriented NNE-SSW, stretches southward on $35 \mathrm{~km}$ from Cape Spartel $\left(35^{\circ} 47^{\prime} \mathrm{N}, 5^{\circ} 56^{\prime} \mathrm{W}\right)$ to the city of Asilah $\left(35^{\circ} 28^{\prime} \mathrm{N}, 6^{\circ} 02^{\prime} \mathrm{W}\right)$ and is punctuated by some villages of Hawara, Had el Gharbia and Briech (Fig. 2a). As confirmed by the historical data this coast is prone to tsunami disasters (Blanc 2008; 2009 and Kaabouben et al. 2009). A detailed analysis of historical collections and archives of 1755 quake has been achieved by numerous researchers but it still remains uncertainties concerning the reliable source of the earthquake and the run-up heights along the coast. Recently, Kaabouben et al. (2009) and Blanc (2009) published contributions in which they assembled and revised historical references of the effects of various tsunami observations, especially from the 1755 event, in some cities of NW Africa. As reported by these historical sources, it appears that the tsunami wave-train was composed of 8 to 9 pulses lasting over $8 \mathrm{~h}$. On the Mediterranean side of Gibraltar Strait, the tsunami flooding height reached about $2.5 \mathrm{~m}$ in Ceuta. The extreme impact occurred in the city of Asilah, where the waves passed over the fortifications, which suggests a run-up of at least $15 \mathrm{~m}$. In the same area, the waves penetrated up to $2 \mathrm{~km}$ inland. The effects were weaker in southern cities like Salé, El Jadida (Mazagao) and Safi; where the maximum tsunami inundation extent reaches respectively $1.2 \mathrm{~km}$ and $2 \mathrm{~km}$. Historical sources in El Jadida propose a run-up of $22.5 \mathrm{~m}$, although this fact is unreliable. The uprush of the successive waves and their subsequent backwash resulted in the drag and deposition of sediments; ships and a large number of fish landward (Fowke 1756). It also caused strong erosion and deposition in some areas, such as in Sidi Moussa, south of El Jadida, where rocks were exposed (Rodríguez-Vidal et al. 2011; Mellas et al. 2012).

However, Blanc (2009) revises and carefully deliberates the different information sources. He concluded that the tsunami was not greater in Africa than in Cádiz. Considering the data provided by Godin (1755), this author proposed a half amplitude of $2.5 \mathrm{~m}$ i.e. height at shoreline minus expected tide level, decreasing to $2 \mathrm{~m}$ and $1.5 \mathrm{~m}$ further south along the coasts of Morocco. Thus, the run-up is reduced and a $5 \mathrm{~m}$ total amplitude, similar to the value estimated in other points of the Moroccan coast.

Later, Omira et al. (2012), using tsunami numerical simulations clarifies and discusses reliability of historical tsunami reports along the coasts of Morocco. Results of tsunami simulations, from 5 most probable sources GBF, $\mathrm{MPF}+\mathrm{HSF}, \mathrm{PBF}$ and CWF indicate that the composite tsunami scenario (MPF $+\mathrm{HSF}$ ) presents some degree of compatibly with the historical tsunami observations along the Gulf of Cadiz coasts concerning the distribution of tsunami energy. Also, the computed maximum wave heights at El-Jadida reaches $6 \mathrm{~m}$ as maximum value for a $\mathrm{Mb} 8.6$ scenario and show a large disagreement with the "wave height" values quoted in historical documents ("75 pieds" $24.6 \mathrm{~m}$ ), when using a mean fault slip value of $10 \mathrm{~m}$.

\section{Tahaddart site}

The field survey was carried out in November 2012 and resulted in a sedimentological data set of the Pleistocene and Holocene deposits. We examined different sites along the Moroccan Atlantic coast, including Sidi Kacem, Ain Guemmout and Tahaddart. In this paper, we focus our investigations on the Tahaddart area where the morphologic and sedimentary records are particularly well preserved and the chronological control assumed. The study area is located $3 \mathrm{~km}$ at south of the confluence of the Oued Mharhar and Oued Hachef. On the left bank of the Oued Hachef, where the sea shore is oriented N10-N190, three Pleistocene dunes are oriented along a N333-N153 (NW-SE) axis, stretching from 1 to $1.5 \mathrm{~km}$ from the sea front. From the beach to the continent, the heights of the dunes are respectively $8 \mathrm{~m}, 6 \mathrm{~m}$ and $7 \mathrm{~m}$, (Figs. $2 \mathrm{c}$ and $3 \mathrm{a}$ ).

The first dune located near to the sea (proximal dune):

i) A pit carved at the foot of this dune displays an interesting outcrop where a succession of three facies can be observed (Fig. 3e): at the base, with a thickness of at least $1.6 \mathrm{~m}$, an accumulation of planar beds alternate with partial carbonate accumulation in finer beds. This first layer is covered by a $70 \mathrm{~cm}$ thick transgressive sandy matrix-supported conglomerate composed of imbricated rounded pebbles. This conglomerate is covered by the material of the dune.

ii) The body of this proximal dune is composed of fine sandy material, the color is clear-brown and numerous carbonate concretions $(\varnothing 4-5 \mathrm{~cm})$ of a former paleosoil are distributed within the material of the upper part of the dune.

iii) At the top, the soil is truncated and replaced by a 10 to $20 \mathrm{~cm}$ thick layer corresponding to an accumulation of carbonate concretions (Fig. 3d). This non matrix supported layer constitutes a residual paving-like overlay on the dune.

The second dune or intermediate dune displays the same surface that characterizes the proximal dune: a 

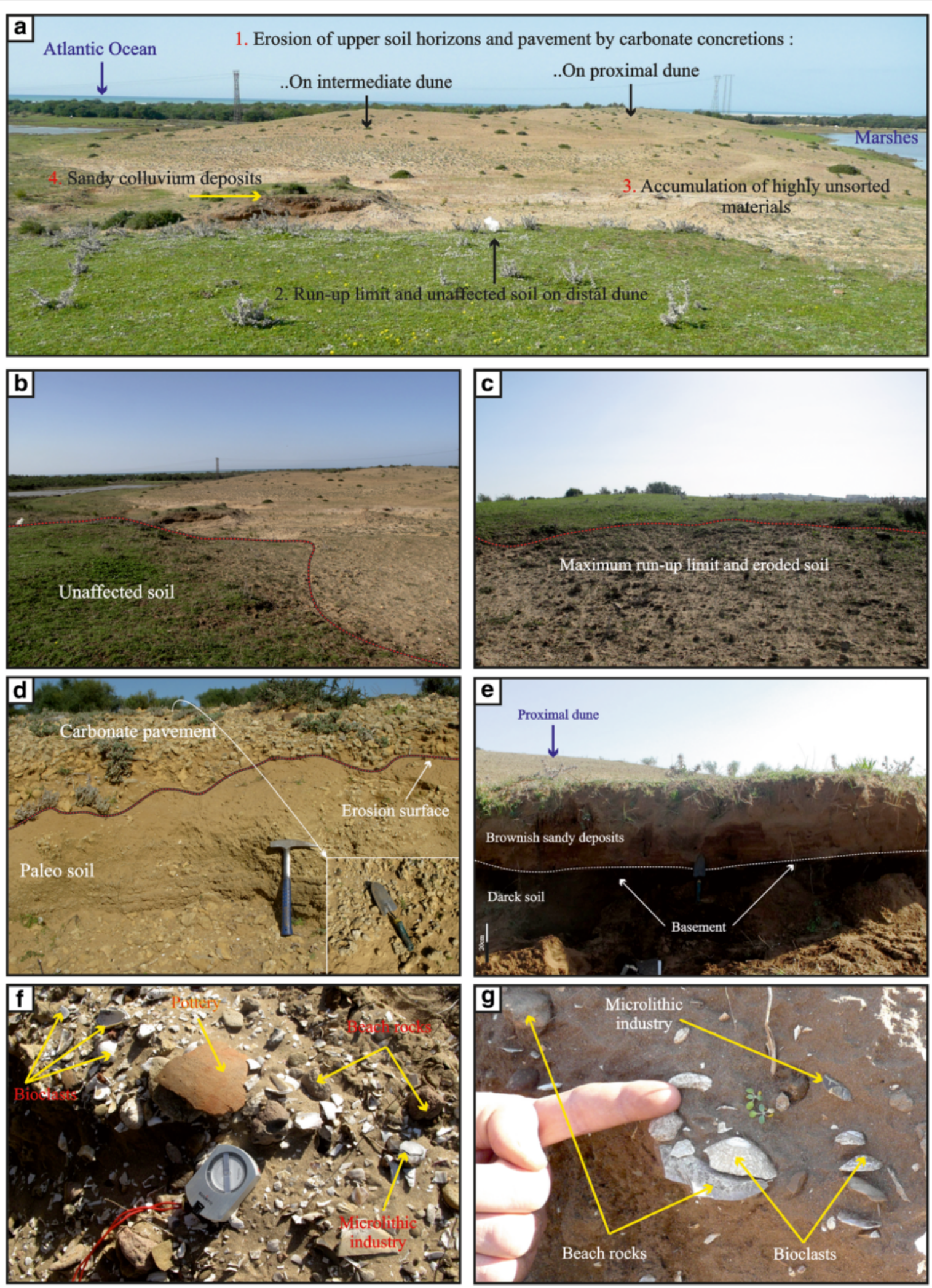

Fig. 3 (See legend on next page.) 
(See figure on previous page.)

Fig. 3 From the top of distal dune, facing N 333 we see in a general view to the Atlantic, notice the lack of vegetation on the proximal and intermediate dune; $\mathbf{b}$ Eroded landscape and unaffected soil; c opposite view to the maximum run-up limit; $\mathbf{d}$ Section in the proximal dune: on the lower part, the sand with the roots of a truncated paleosoil, on the upper part a pavement of residual carbonates concretions, notice the strong unconformity; e sand accumulation on basement of proximal dune, the brown organic matter removed from the upper dune; $\mathbf{f}$ Surface accumulation of highly marine unsorted materials on interdune gaps, including pottery, microliths, and marine fauna; $\mathbf{g}$ Section in a basal accumulation with brown sand, marine shell, microlithic industry, beach rocks

thick layer of residual pedologic carbonate concretions covers the dune resulting from a severe troncature of a former paleosoil. No outcrop allows providing information concerning the dune basal structure.

The third dune or distal dune shows the same internal composition but at the top, no carbonate concretions armor can be seen. At the top, a brown soil is present. It is covered (Fig. 3b-c) by low but dense grassy vegetation.

From the proximal to the distal dune, the soil surface is completely different. The scarce vegetation cover growing on a lithic soil composed by an accumulation of carbonate concretions that can be seen on the proximal and intermediate dunes contrast with the dense vegetation growing on a unaffected soil on the distal dune. This attests that severe erosion affected the soil and the upper part of the proximal and intermediate dunes. This strong erosion explains the significant colluvium accumulations within the first inter-dunes low. No erosion occurred on the distal dune.

The second inter-dunes pass is covered by beach rock clasts, bioclasts including Cerastoderma edule, Venus verrucosa, Patella caerulea, Mytilus galloprovincialis, Strombus bubonius, lithic artifacts and remnants of circular stone structure. The lower part of this inter-dune, where the greater accumulation of sand eroded from the dunes occurred, was particularly interesting. The sections show the sand, beach rock pebbles, bioclasts, lithic artifacts, removed from the upper slopes (Fig. 3g).

On the specific small area, located between the Tangier and Asilah cities, no written texts exist. Despite that, we have prehistoric and geomorphologic arguments for the youth of the hydrodynamic event described here.

a) On the lower part of the second dune, a tomb (Otte and Abdellaoui, 2004) dated $5930 \pm 40$ years BP corrected ( 2 sigma). The description by these authors attributes a continental origin to the sand and gastropod in the tomb opposed to marine shells and broken oysters on the surface. The broken so called pottery "a cannelures" collected in this area by El Idrissi (2012) is dated around $6000 \mathrm{BP} \approx 4860 \mathrm{BC}$. This good agreement between the skeleton found in the tomb and the pottery indicate a maximum age of $4800 \mathrm{BC}$ for the event here described. South of our area the geomorphology of Loukkos estuary is described by Carmina and Ruiz (2009), in this valley a high energy event has been evidenced by (Mhammdi et al. 2015). On another hand; the historical documents (Mendonça 1758) indicate that the last important roman buildings were destroyed during the 1755 earthquake.

b) From the geomorphological point of view, the vegetation cover and the weathered soil of the distal dune correspond to the normal pedologic evolution in this humid area during the Holocene. On the contrary, the young landscape of bare soil on the proximal and intermediate dune, calls for explanation. In this context, the consequence of a probable 250 years old strong erosive event is not to be exclude.

\section{Methods}

Sedimentary characteristics of the deposits were described in situ along three outcrops (Fig. 2c). The outcrop (Th01) was realized at the base of the proximal dune, while (Th02) and (Th03) near the top and on the flank of the second inter-dune low. Sediment samples were collected along outcrops for grain size, anisotropy of magnetic susceptibility and paleontological analysis (Table 1). For the anisotropy of magnetic susceptibility (AMS) and grain-size measurements, samples were collected in $2 \mathrm{~cm}$-sided cubic plastic nonmagnetic boxes along the vertical sections of the outcrops, as described in Wassmer et al. (2010). The anisotropy of magnetic susceptibility (AMS) was measured using a Kappabridge MFK1-A at the "Laboratoire d'Analyses des Sols et des Formations Superficielle », EOST Laboratory, University of Strasbourg. Each sample was analyzed in 64 directions for each axes of the box to reconstruct the anisotropy ellipsoid and determine the magnitude and directions of the maximum (Kmax), intermediate (Kint), and minimum (Kmin) AMS axes. Grain-size analyses were performed for each sample with a laser diffraction microgranulometer Coulter at the EOST Laboratory. Prior to grain size analysis, samples were heated in a hydrogen peroxide solution to destroy organic material. Summary statistics presented here include geometric mean grain size $(\mu \mathrm{m})$, sand content $(\%)$, mud content $(\%)$, sorting $(\Phi)$, skewness $(\Phi)$, and kurtosis $(\Phi)$.

The samples for micropalaeontological analysis (18 samples) were all from the sediment suspected to be emplaced by a high energy flooding (see Table 1), except for 
Table 1 Samples taken from the outcrops with sampling depth, individual type of grain size analysis (WS = wet sieving; $L=$ laser diffraction; AMS = Anisotropy of magnetic susceptibility) and foraminifera tests with results of micropalaeontology (SF = shell fragments; gastr = marine gastropods; GL sp. = Globigerina sp.; EL cr. = Elphidium crispum; AM tep sp. = Ammonia tepida sp.; AM bec. = Ammonia beccarii; BU sp. = Bulimina sp.; No sp. = Nodosaria sp.

\begin{tabular}{|c|c|c|c|c|c|}
\hline & & $\begin{array}{l}\text { Type of grain } \\
\text { size analysis }\end{array}$ & $\begin{array}{l}\text { AMS } \\
\text { analysis }\end{array}$ & $\begin{array}{l}\text { Foraminifera } \\
\text { analysis }\end{array}$ & Micropalaeontology \\
\hline & Outcrop Th01 & & & & \\
\hline S1a & $0-10 \mathrm{~cm}$ & WS & - & $\checkmark$ & SF; gastr.; GL sp.; EL cr.; AM tep sp.; AM bec \\
\hline S1b & $10-20 \mathrm{~cm}$ & WS & - & $\checkmark$ & SF; gastr.; GL sp.; EL cr.; AM tep sp.; AM bec \\
\hline S1c & $20-30 \mathrm{~cm}$ & L & $\checkmark$ & $\checkmark$ & SF; gastr.; GL sp.; EL cr.; AM tep sp.; AM bec \\
\hline S1d & $30-40 \mathrm{~cm}$ & L & $\checkmark$ & $\checkmark$ & SF; gastr.; GL sp.; EL cr.; AM tep sp.; AM bec \\
\hline S1e & $40-50 \mathrm{~cm}$ & L & $\checkmark$ & $\checkmark$ & SF; gastr.; GL sp.; EL cr.; AM tep sp.; AM bec \\
\hline Sif & $50-60 \mathrm{~cm}$ & L & $\checkmark$ & $\checkmark$ & SF; gastr.; GL sp.; EL cr.; AM tep sp.; AM bec \\
\hline \multirow[t]{2}{*}{ S1g } & $60-70 \mathrm{~cm}$ & & & & \\
\hline & Outcrop Th02 & & & & \\
\hline S2a & $0-30 \mathrm{~cm}$ & WS & - & $\checkmark$ & SF; gastr. \\
\hline S2b & $30-45 \mathrm{~cm}$ & WS & - & $\checkmark$ & SF; EL cr.; gastr. \\
\hline S2C & $45-47 \mathrm{~cm}$ & L & $\checkmark$ & $\checkmark$ & SF; GL sp. (rew.); EL cr.; AM sp.; \\
\hline S2d & $47-49 \mathrm{~cm}$ & L & $\checkmark$ & $\checkmark$ & SF; GL sp. (rew.); EL cr.; AM sp.; \\
\hline S2e & $49-51 \mathrm{~cm}$ & L & $\checkmark$ & $\checkmark$ & SF; GL sp. (rew.); EL cr.; AM sp.; \\
\hline S2f & $51-53 \mathrm{~cm}$ & L & $\checkmark$ & $\checkmark$ & SF; GL sp. (rew.); EL cr.; AM sp.; \\
\hline S2j & $53-55 \mathrm{~cm}$ & L & $\checkmark$ & $\checkmark$ & SF; GL sp. (rew.); EL cr.; AM sp.; \\
\hline \multirow[t]{2}{*}{$\mathrm{S} 2 \mathrm{~h}$} & $55-57 \mathrm{~cm}$ & L & $\checkmark$ & $\checkmark$ & SF; GL sp. (rew.); EL cr.; AM sp.; \\
\hline & Outcrop Th03 & & & & \\
\hline S3a & $0-20 \mathrm{~cm}$ & L & $\checkmark$ & $\checkmark$ & SF; GL sp. (rew.); EL cr.; AM sp.; GL sp; \\
\hline S3b & $20-30 \mathrm{~cm}$ & L & $\checkmark$ & $\checkmark$ & SF; GL sp. (rew.); EL cr.; AM sp.; No p; \\
\hline $\mathrm{S3C}$ & $30-40 \mathrm{~cm}$ & L & $\checkmark$ & $\checkmark$ & SF; GL sp. (rew.); EL cr.; AM sp.; OR sp; \\
\hline S3d & $40-42 \mathrm{~cm}$ & L & $\checkmark$ & $\checkmark$ & SF; GL sp. (rew.); EL cr.; AM sp.; No sp; GL sp; \\
\hline \multirow[t]{2}{*}{ S3e } & $42-44 \mathrm{~cm}$ & L & $\checkmark$ & $\checkmark$ & SF; GL sp. (rew.); EL cr.; AM sp.; GL sp; \\
\hline & Beach (Tahaddart) & & & & \\
\hline \multirow[t]{2}{*}{$\mathrm{Sb}$} & $0-30 \mathrm{~cm}$ & WS & - & $\checkmark$ & EL cr.; SF; gastr.; EL cr.; AM sp.; \\
\hline & Marshlands & & & & \\
\hline$S M_{1}$ & 0-30 cm (O. Hachef) & WS & - & $\checkmark$ & EL cr.; SF; gastr. OR uni sp.; No sp.; \\
\hline $\mathrm{SM}_{2}$ & 0-30 cm (O. Mharhar) & WS & - & $\checkmark$ & EL cr.; SF; gastr. OR uni sp.; No sp.; GL sp. (rew.); \\
\hline
\end{tabular}

reference samples from the modern beach and adjacent marshlands. The samples were cleaned by removing sediments finer than $63 \mu \mathrm{m}$. The sieved samples were dried at $40{ }^{\circ} \mathrm{C}$ following the methods of Horton and Edwards (2006). The mud content was calculated from the difference of the dry weight of the original sample and its coarse fraction in the sieve. Size distributions of foraminiferal tests and sediment grains were analyzed using a series of coarser sieves with mesh sizes of 90, 125, 180, 250, 355, $500,710,1000,1400$, and $2000 \mu \mathrm{m}$. Each sample was divided into subsamples, each of which included about 300 foraminiferal tests (Horton and Edwards 2006). All foraminiferal tests in each subsample were counted and identified to species level under a stereo optical microscope.
Mean test sizes of planktonic foraminifera, which were in sufficient numbers for statistical analysis, were calculated at the size intervals corresponding to the coarse sieves (Loeblich and Tappan 1988; Hayward et al. 2004).

\section{Results}

\section{Sedimentological analysis}

We present here the results obtained for the three outcrops, sampled close to the two inter-dune pass in the Tahaddart lowland. The studied deposits are medium to fine, greyish to yellowish sands, displaying important variations in thickness, color, and grain size (Fig. 4). The thickness of the deposits varies from 60 to $80 \mathrm{~cm}$. They correspond to sandy material emplaced in topographical 


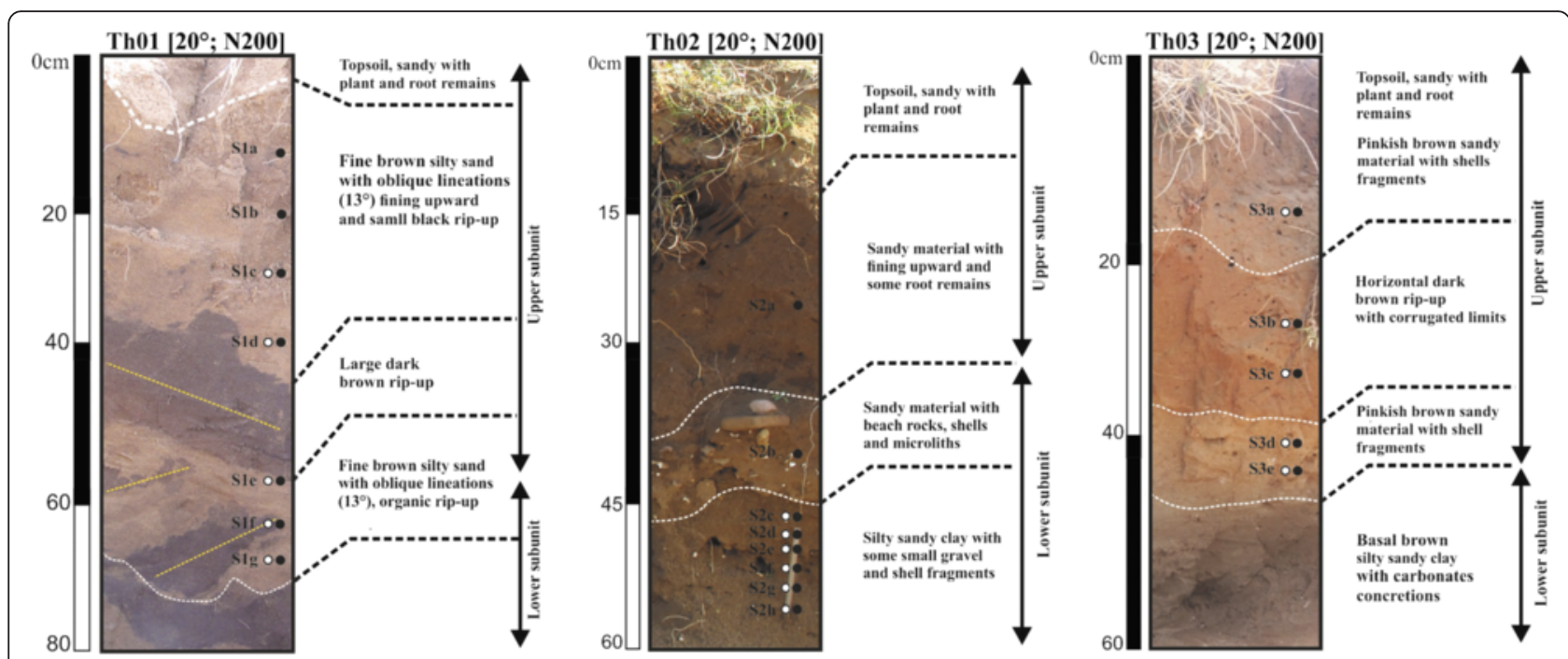

Fig. 4 Sedimentological analysis and interpretation of outcrop from the study area (for location see Fig. 2c). The white and black circles represent the samples for anisotropy of magnetic susceptibility and grain size analysis, respectively

lows: inter-dune gap between intermediate and distal dune $(60 \mathrm{~cm})$ and near the proximal dune $(80 \mathrm{~cm}$, outcrop Th01); but also on a small hill of thick brownish sandy colluvium deposits $(70 \mathrm{~cm}$, outcrop Th02) and on a small sand cliff near the distal dune (60 cm, outcropTh03).

The outcrop Th01 is subdivided into 2 subunits (Fig. 4a):

i). Lower sub-unit (depth $80-70 \mathrm{~cm}$ ): Starts by reverse graded basal brownish sands (see formation on Fig. 5), containing an accumulation (20 to $30 \mathrm{~cm}$ in thickness) of carbonate concretions and rip-up clasts of the underlying dark grey silt and dark brown organic matter (OM). Above a $20 \mathrm{~cm}$ thick interval $(70-50 \mathrm{~cm})$ of fine to very fine-grained sand displaying rough scour and fill structures undulating with curved laminae filling tilted dark mud flakes. This layer is characterized by the inclusion of numerous dark-brown mud-clasts clasts with a diameter ranging from (15 to $25 \mathrm{~cm}$ ). They are

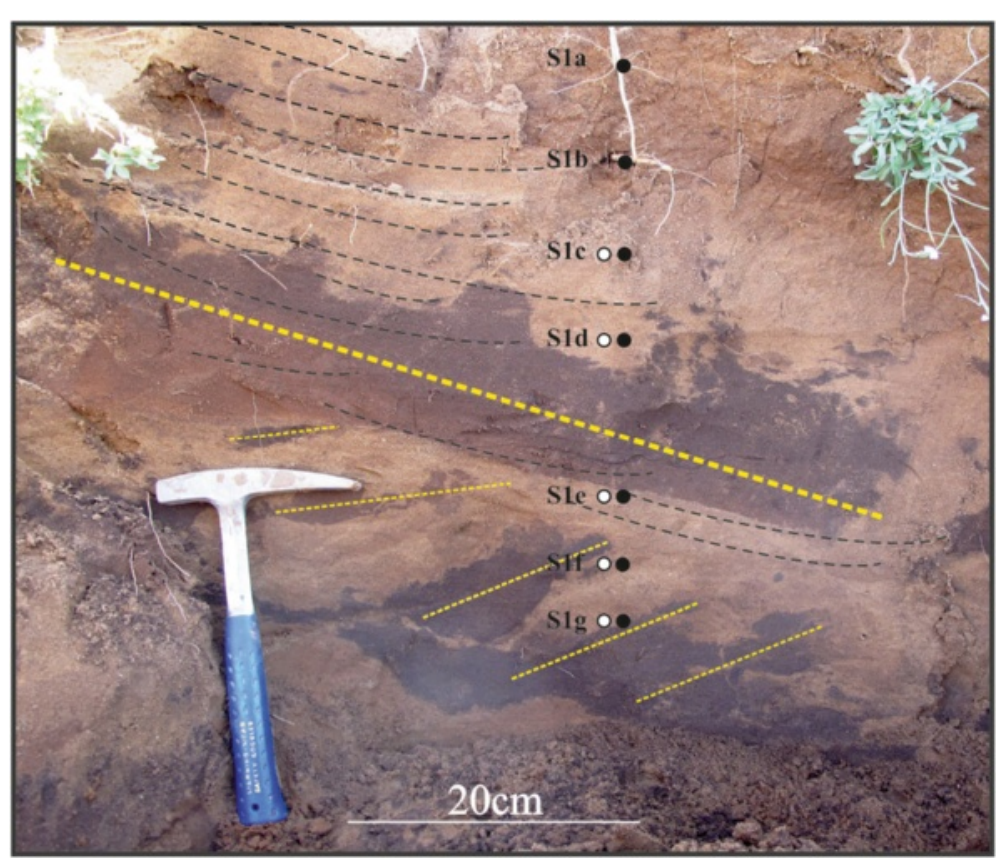

Fig. 5 Outcrop Th01, showing oblique injections and rip-up clasts of pre-tsunami dark grey clay in tsunami subunit 
elongated, display blunted edges and are tilted $10^{\circ}$ to the NW (Fig. 5).

ii). Upper sub-unit $(50-10 \mathrm{~cm})$ : This layer shows at the base an erosive contact with the lower sub-unit. Composed of yellowish-brown medium to fine sands, mixed with grey fine sands it displays at the base a large clast up to $80 \mathrm{~cm}$ in size. The shape of the clast is angular to sub-angular and tilted to the SE $\left(13^{\circ}\right)$, some fragments are released from its rear upper surface and stretched in a NW direction (Fig. 5). The upper part of the deposits corresponds to fine-grained reworked aeolian sands.

The outcrop Th02 is located at the south-west foot of distal dune (Fig. 2c). This outcrop is organized vertically in two main subunits (Fig. 4b): $i$ ). Lower sub-unit (45$60 \mathrm{~cm}$ ): is constituted by a thick layer of brownish massive sands exempt of any visual sedimentary structures, it is covered by a $10-15 \mathrm{~cm}$ layer of various origins clastic material: microlithic industry artefacts, numerous broken pieces of potteries all displaying blunt breaks, broken shells in abundance (Fig. 3g). ii). Upper sub-unit $(10-50 \mathrm{~cm})$ : is constituted by fine-grained brown colluvium sands with many marine bioclasts fragment. At the very top of the sequence, a 4-6 cm layer of fine pale sands is colonized by scarce grassy vegetation.

The outcrop Th03 is subdivided also into 2 sub-units (Fig. 4c): i). Lower sub-unit $(60-40 \mathrm{~cm})$ : brownish-dark fine sands mixed with grey fine silt, with a basal erosive contact. Many marine bioclasts (very fine shell fragments of bivalves, gastropods are found in the lower part of the sub-unit. ii). Upper sub-unit $(0-40 \mathrm{~cm})$ : a layer up to $40 \mathrm{~cm}$ in thickness is composed of medium to fine pinkish sand with very few shell fragments. The central part of upper sub-unit is complex, showing horizontal large clast $(20 \mathrm{~cm})$ of dark-brown sandy material displaying corrugated limits. The upper part of this sub-unit is covered by a layer of yellowish sand and silts. Frequent wood fragments were found near the top of the sub-unit.

\section{Texture and grain size distribution}

To get optimal information on transport and emplacement mechanisms of the tsunami deposits, it is important to consider the grain-size data of the sediments to better constrain the AMS data. Results of grain size distribution are summarized in Table 2. Deposits consist of coarse sand to silt. Grain size distribution for the tsunami deposit confirms a clear predominance of sand $(95.55 \%)$ and a very weak content of silt $(2.74 \%)$ and clay $(1.72 \%)$.

The frequency grain-size curves are multi-modal, and the mean grain size ranges from 105.34 to $251.90 \mu \mathrm{m}$. In individual sequences, the standard deviations are between 0.89 and 1.99 . It generally increases from the base to the top of the deposits. The standard deviation at the base of outcrop Th03 reaches 1.52, probably as the result of the presence of rip-up clasts which polluted the sand with an important amount of clay. On the contrary, the skewness ranges from 0.91 to 1.09 , and decreases vertically (Fig. 6). Similar trends are observable for the superimposed deposit intervals in all other sections. Finally, data corresponding to all samples were reported for outcrops Th01, Th02 and Th03 in the Passega C-M diagram (Passega, 1957, 1964).

\section{Anisotropy of magnetic susceptibility}

Anisotropy of Magnetic Susceptibility is a common tool in geology for determination of a rock overall fabric. Wassmer et al. 2010 demonstrated that AMS applied to unconsolidated tsunami deposits can give information on sediment fabrics and depositional processes, "Its accurate applicability to practically every kind of rock and soft sediment, and the high sensitivity and repeatability of the measurements, allow fabric determination even in rocks lacking classical mesoscopic structural markers".

For a sample collected on the sediment in the field, the ellipsoid of anisotropy is reconstructed thanks to the help of a Kappabridge MFK1-A (AGICO). The anisotropy ellipsoid is characterized by three main axes each perpendicular to the others, i.e. Kmax, Kint and Kmin. The anisotropy of each sample (i.e. each cubic box) can be visualised by a triaxial ellipsoid (the maximum, intermediate and minimum axes corresponding to principal eigenvectors). The calculation of AMS parameters such as the corrected degree of anisotropy (Pj), magnetic lineation (L) and foliation (F), alignment parameter (Fs) and shape parameter $(\mathrm{T})$ allows evaluating relationships between magnetic fabrics and depositional processes to be investigated. The alignment parameter represents the development of a linear fabric and thus increases with bottom current strength. The shape parameter describes the geometry of the AMS ellipsoid, which is oblate for $\mathrm{T}>0$ (settling mode) or prolate for $\mathrm{T}<0$ (traction mode). It has been demonstrated that the mean orientation of the grain's long axis (and thus the maximum tensor axis, Kmax), is parallel to low direction for moderate currents and settling from suspension. For stronger currents with dominant traction (bed load), the long axis of prolate particles (Kmax) tends to be orientated perpendicular to low direction (see review in Wassmer et al. 2010; Wassmer and Gomez 2011; Kain et al. 2014).

The mean bulk volume susceptibilities K (Table 3), depending on the mineral composition of the sediment, range from 1.0035 to $1.0122 \times 10^{-3} \mathrm{SI}$ in the whole set of samples, with an average of $1.00422 \times 10^{-3} \mathrm{SI}$. There is no apparent relationship between bulk volume susceptibilities and grain size of the sediments, and no clear 
Table 2 Grain-size parameters (mean size in um; standard deviation; skewness; C95, C90, C50, C10, in $\mu$ m, are 95, 90, 50 and 10 probability cumulative percent, respectively), for outcrops Th 01, Th02 and Th03

\begin{tabular}{|c|c|c|c|c|c|c|c|c|c|c|c|}
\hline \multicolumn{2}{|c|}{ Samples } & \multirow[t]{2}{*}{ \% Sand } & \multirow[t]{2}{*}{$\%$ Silt } & \multirow[t]{2}{*}{$\%$ Clay } & \multirow[t]{2}{*}{ Mean $(\mu \mathrm{m})$} & \multirow[t]{2}{*}{ Skewness } & \multirow[t]{2}{*}{ Sorting } & \multirow[t]{2}{*}{ C95 } & \multirow[t]{2}{*}{ C90 } & \multirow[t]{2}{*}{ C50 } & \multirow[t]{2}{*}{$\mathrm{C} 10$} \\
\hline & Outcrop Th01 & & & & & & & & & & \\
\hline S1a & $0-10 \mathrm{~cm}$ & 96.05 & 2.21 & 1.74 & 219.25 & 1.089 & 1.195 & 329.4 & 318.4 & 211.2 & 129.7 \\
\hline$S 1 b$ & $10-20 \mathrm{~cm}$ & 96.21 & 2.07 & 1.72 & 221.33 & 1.09 & 1.19 & 331.4 & 223.1 & 209.2 & 126.5 \\
\hline S1C & $20-30 \mathrm{~cm}$ & 97.21 & 1.43 & 1.36 & 229.45 & 1.097 & 1.263 & 373.1 & 339.8 & 213.2 & 146.8 \\
\hline S1d & $30-40 \mathrm{~cm}$ & 95.72 & 2.71 & 1.57 & 229.45 & 1.097 & 1.263 & 716.9 & 339.8 & 213.8 & 121.8 \\
\hline S1e & $40-50 \mathrm{~cm}$ & 97.29 & 1.61 & 1.1 & 229.45 & 0.91 & 1.263 & 541.9 & 339.8 & 234.1 & 146.8 \\
\hline S1f & $50-60 \mathrm{~cm}$ & 96.44 & 2.19 & 1.37 & 216.88 & 0.999 & 1.205 & 373.1 & 309.6 & 213.2 & 133.7 \\
\hline \multirow[t]{2}{*}{ S1g } & $60-70 \mathrm{~cm}$ & 95.69 & 2.79 & 1.52 & 221.65 & 1 & 1.323 & 449.7 & 339.6 & 213.2 & 121.8 \\
\hline & Outcrop Th02 & & & & & & & & & & \\
\hline S2a & $0-30 \mathrm{~cm}$ & 96.72 & 1.34 & 1.94 & 219.6 & 0.989 & 1.107 & 332.5 & 312.7 & 219.5 & 129.6 \\
\hline$S 2 b$ & $30-60 \mathrm{~cm}$ & 96.67 & 1.98 & 1.35 & 218.9 & 0.99 & 1.105 & 336.1 & 313.4 & 223.6 & 119.9 \\
\hline$S 2 C$ & $60-62 \mathrm{~cm}$ & 97.06 & 1.67 & 1.27 & 216.8 & 0.999 & 1.205 & 339.8 & 309.6 & 213.2 & 133.7 \\
\hline S2d & $62-64 \mathrm{~cm}$ & 97.19 & 1.53 & 1.28 & 216.8 & 0.999 & 1.205 & 309.6 & 282.1 & 213.2 & 133.7 \\
\hline S2e & $64-66 \mathrm{~cm}$ & 95.52 & 2.74 & 1.74 & 209.1 & 0.911 & 1.262 & 309.6 & 282.1 & 213.2 & 121.8 \\
\hline S2f & $66-68 \mathrm{~cm}$ & 97.02 & 1.57 & 1.41 & 216.8 & 0.999 & 1.205 & 339.8 & 309.6 & 213.2 & 133.7 \\
\hline S2g & $68-70 \mathrm{~cm}$ & 94.14 & 3.84 & 2.02 & 197.65 & 0.999 & 1.323 & 309.6 & 282.1 & 194.2 & 92.65 \\
\hline \multirow[t]{2}{*}{$\mathrm{S} 2 \mathrm{~h}$} & $70-72 \mathrm{~cm}$ & 94.07 & 3.83 & 2.1 & 197.65 & 1.001 & 1.205 & 309.6 & 282.1 & 194.2 & 101.1 \\
\hline & Outcrop Th03 & & & & & & & & & & \\
\hline S3a & $0-30 \mathrm{~cm}$ & 96.31 & 2.24 & 1.45 & 229.4 & 0.916 & 1.263 & 493.6 & 373.1 & 234.1 & 133.7 \\
\hline S3b & $30-40 \mathrm{~cm}$ & 97.01 & 1.73 & 1.26 & 251.9 & 1.097 & 1.263 & 493.6 & 373.1 & 234.1 & 146.8 \\
\hline S3C & $40-50 \mathrm{~cm}$ & 95.51 & 2.96 & 1.53 & 251.9 & 1.097 & 1.263 & 373.1 & 339.8 & 213.2 & 111 \\
\hline S3d & $50-60 \mathrm{~cm}$ & 96.51 & 2.14 & 1.35 & 251.9 & 0.916 & 1.263 & 373.1 & 339.8 & 234.1 & 133.7 \\
\hline \multirow[t]{2}{*}{ S3e } & $60-70 \mathrm{~cm}$ & 93.7 & 4.33 & 1.97 & 221.6 & 1 & 1.323 & 339.8 & 309.6 & 213.2 & 92.09 \\
\hline & Beach (Tahaddart) & & & & & & & & & & \\
\hline \multirow[t]{2}{*}{$\mathrm{Sb}$} & $0-30 \mathrm{~cm}$ & 94.19 & 3.95 & 1.86 & 599.3 & 1.963 & 0.891 & 389.5 & 307.1 & 241.9 & 190.3 \\
\hline & Marshlands & & & & & & & & & & \\
\hline SM1 & 0-30 cm (O. Hachef) & 97.58 & 2.24 & 2.19 & 105.3 & 2.985 & 2.443 & 248.6 & 315.5 & 226.5 & 58.51 \\
\hline SM2 & 0-30 cm (O. Mharhar) & 85.1 & 8.63 & 6.27 & 199.18 & 2.83 & 2.512 & 220.58 & 452.89 & 242.89 & 95.29 \\
\hline
\end{tabular}

variations of $\mathrm{K}$ are observed with those of the structure of the deposits. According to the mineral composition of the studied sediments, K values very likely reflect the influence of oxide ferromagnetic minerals and, also but in lesser amounts, of paramagnetic minerals as biotite and amphibole that can be present in relatively important, but variable, proportions. These variations in magnetic mineral contents could explain the fluctuations of the $\mathrm{K}$ values. On the contrary, AMS parameters as lineation ( $\mathrm{L}=1.0075$ on average), foliation ( $\mathrm{F}=1.0053$ on average), corrected degree of anisotropy $(\mathrm{Pj}=1.013$ on average) and shape parameter ( $\mathrm{T}=0.184$ on average) display correlations with the vertical lithologic changes in the deposits. $\mathrm{L}, \mathrm{F}$ and $\mathrm{T}$ values indicate that the AMS ellipsoids are mainly oblate, with variation in their prolate component.
The AMS data of outcrops are presented on Fig. 7. The five samples, within the outcrop Th01, were collected in the upper member of the thick sandy layer containing dark-brown clasts visible on Fig. 5. Flow direction evidenced by AMS gives an overall NW direction for the flow. It corresponds to a seaward flow.

The outcrop Th02 emplaced at the foot of the third hill begins by an uprush flow oriented toward the SouthEast (N105). The flow turned shortly then to the South (N171). Sample S2e can be interpreted as a backwash flow as it appears to be oriented toward North -West (N297). This backwash possibility is restrained by the weak tilting $\left(6^{\circ}\right)$ in reason of its position very close to the limit of the confidence area. This confidence area, comprised between 0 and $5^{\circ}$, comes up with the difficulty to plug the boxes perfectly horizontally in the 


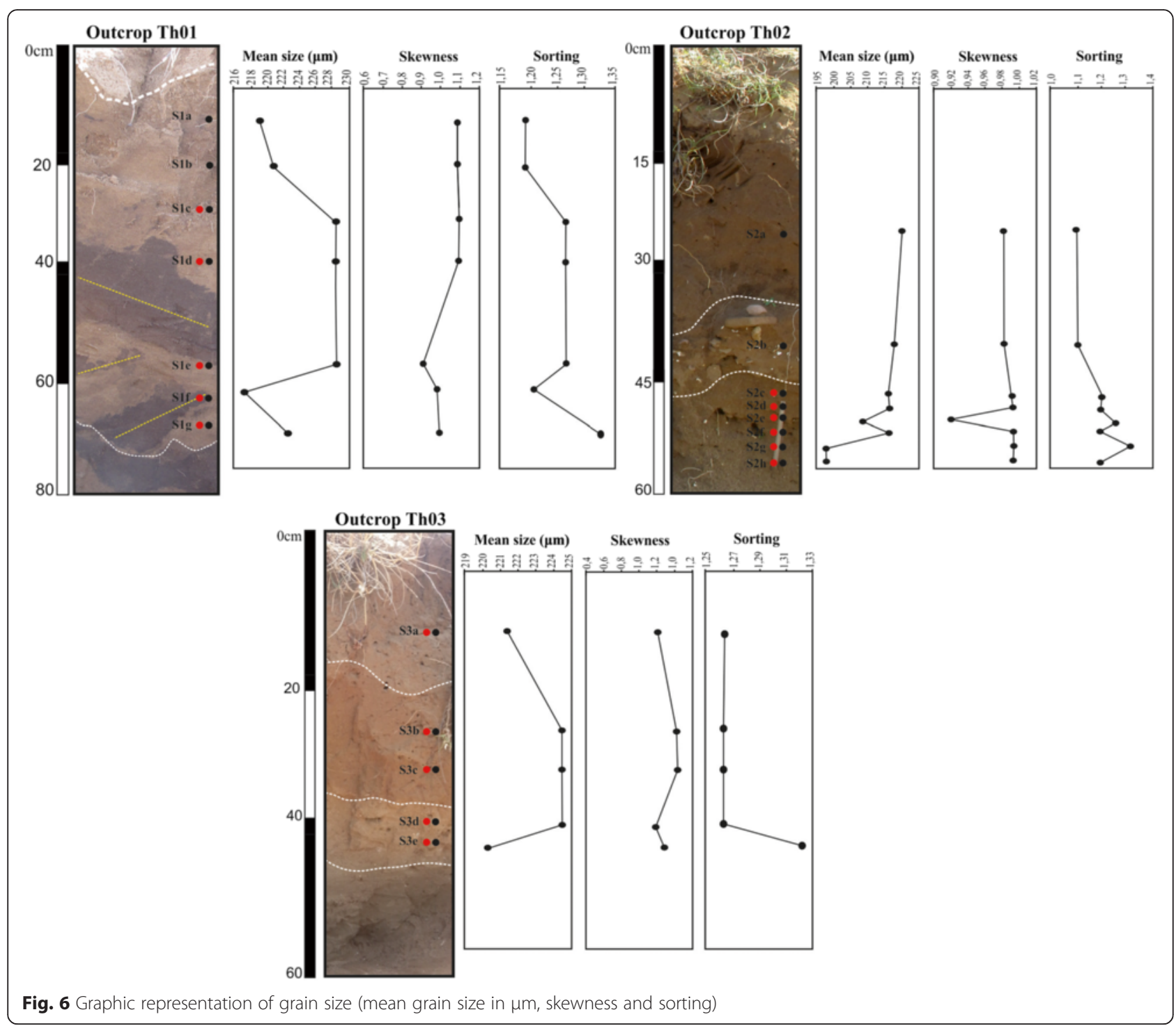

sediment during sampling. The flow pushed then to the East for samples S2f (N91) and S2j (N98) before taking a South-East orientation (N124). The outcrop Th03 is located at the upper part of a pass oriented ENE-WSW. The lower samples S3e and S3d can be interpreted as an uprush flow oriented to the ESE. The upper samples S3b, S3c and S3a are completely different and give a global direction to WSW, which correspond to a channelization of the flow towards an empty space located south of the dunes.

\section{Recent and fossil foraminifera}

The foraminiferal assemblage within the modern beach samples is relatively low. Some shell debris, some gastropods as well as some Elphidium crispum were found but these were undoubtedly reworked. The samples from sand deposit (Table 1) do not have as much shell debris as the beach samples; however, within the sampled deposits from the tsunami layers several Globigerina sp., sea-urchin radiols, Elphidium crispum, Nonion boueanum; Bulimina; Orbulina universa sp., as well as a some individual Sphaeroidinellopsis sp. were found. Additionally, individual Ammonia beccarii were found within the samples from the interdune sandy layer deposits. The foraminiferal accumulation of the marshland samples has numbers of each poorly conserved and reworked species. Similar to the sedimentology, the micropaleontological characteristics can vary on a local to regional scale, including abundance, salinity preference, life form and habitat (Hindson et al. 1996; Mamo et al. 2009). At Tahhadart, ostracoda were absent in the tsunami deposit, whereas foraminifera and mollusca were abundant. Broken foraminifera valve was found in the lower layer. The upper layer contained planktonic foraminifera 
Table 3 AMS parameters and densities for Sections A to G. and Section BP

\begin{tabular}{|c|c|c|c|c|c|c|c|c|c|c|c|c|c|c|}
\hline & Samples & Kmax & Kint & Kmin & $D^{\circ}$ & $1^{\circ}$ & $\mathrm{D}^{\circ}$ & $1^{\circ}$ & L & $F$ & Pj & $\mathrm{T}$ & Fs & q \\
\hline & Outcrop Th01 & & & & & & & & & & & & & \\
\hline S1C & $20-30 \mathrm{~cm}$ & 1.0089 & 0.9994 & 0.9937 & 106 & 35 & 338 & 41 & 1.012 & 1.004 & 1.016 & -0.509 & 1.024 & 1.215 \\
\hline S1d & $30-40 \mathrm{~cm}$ & 1.0046 & 1.0004 & 0.9951 & 117 & 5 & 13 & 71 & 1.004 & 1.005 & 1.01 & 0.124 & 1.013 & 0.563 \\
\hline S1e & $40-50 \mathrm{~cm}$ & 1.0075 & 0.9978 & 0.9946 & 100 & 14 & 206 & 50 & 1.001 & 1.003 & 1.014 & -0.501 & 1.022 & 1.204 \\
\hline S1f & $50-60 \mathrm{~cm}$ & 1.0114 & 0.9995 & 0.9891 & 164 & 8 & 264 & 50 & 1.012 & 1.011 & 1.023 & -0.058 & 1.034 & 0.725 \\
\hline \multirow[t]{2}{*}{ S1g } & $60-70 \mathrm{~cm}$ & 1.0092 & 0.9974 & 0.9933 & 145 & 12 & 345 & 77 & 1.012 & 1.004 & 1.017 & -0.483 & 1.028 & 1.182 \\
\hline & Outcrop Th02 & & & & & & & & & & & & & \\
\hline$S 2 C$ & $60-62 \mathrm{~cm}$ & 1.0066 & 0.9986 & 0.9948 & 304 & 5 & 48 & 69 & 1.008 & 1.004 & 1.012 & -0.345 & 1.019 & 1.016 \\
\hline S2d & $62-64 \mathrm{~cm}$ & 1.0089 & 0.9992 & 0.9919 & 98 & 1 & 7 & 59 & 1.01 & 1.007 & 1.017 & -0.14 & 1.027 & 0.801 \\
\hline S2e & $64-66 \mathrm{~cm}$ & 1.0122 & 0.9975 & 0.9903 & 271 & 15 & 76 & 75 & 1.015 & 1.007 & 1.023 & -0.337 & 1.037 & 1.01 \\
\hline S2f & $66-68 \mathrm{~cm}$ & 1.0073 & 1.0007 & 0.992 & 117 & 6 & 231 & 76 & 1.007 & 1.009 & 1.015 & 0.138 & 1.022 & 0.552 \\
\hline S2g & $68-70 \mathrm{~cm}$ & 1.0073 & 0.9998 & 0.9929 & 351 & 11 & 225 & 72 & 1.008 & 1.007 & 1.015 & -0.046 & 1.022 & 0.711 \\
\hline \multirow[t]{2}{*}{$\mathrm{S} 2 \mathrm{~h}$} & $70-72 \mathrm{~cm}$ & 1.008 & 1.0001 & 0.9919 & 285 & 14 & 63 & 72 & 1.008 & 1.008 & 1.016 & 0.023 & 1.024 & 0.65 \\
\hline & Outcrop Th03 & & & & & & & & & & & & & \\
\hline S3a & $0-30 \mathrm{~cm}$ & 1.0024 & 1 & 0.9976 & 54 & 6 & 161 & 71 & 1.002 & 1.002 & 1.005 & 0.015 & 1.007 & 0.654 \\
\hline S3b & $30-40 \mathrm{~cm}$ & 1.0051 & 1.0003 & 0.9947 & 36 & 37 & 299 & 9 & 1.005 & 1.006 & 1.01 & 0.078 & 1.013 & 0.601 \\
\hline S3c & $40-50 \mathrm{~cm}$ & 1.0035 & 1.0006 & 0.9959 & 75 & 14 & 188 & 58 & 1.003 & 1.005 & 1.008 & 0.256 & 1.01 & 0.459 \\
\hline S3d & $50-60 \mathrm{~cm}$ & 1.003 & 0.9994 & 0.9977 & 308 & 6 & 212 & 43 & 1.004 & 1.002 & 1.005 & -0.36 & 1.0089 & 1.031 \\
\hline S3e & $60-70 \mathrm{~cm}$ & 1.0072 & 0.9969 & 0.9958 & 281 & 8 & 184 & 41 & 1.01 & 1.001 & 1.013 & -0.81 & 1.021 & 1.654 \\
\hline
\end{tabular}

K: mean bulk volume susceptibility in $10^{-3} \mathrm{SI}$ units; Kmax. Kint and Kmin: respectively maximum, intermediate and minimum axes of the anisotropy ellipsoid defined in intensity normalized to the bulk volume susceptibility; $\mathrm{D}^{\circ}$ and $\mathrm{I}^{\circ}$ : respectively declination and inclination in degrees for the maximal and minimal axes; $\mathrm{L}$ : is the magnetic lineation; F: is the magnetic foliation; Pj: corrected anisotropy degree; T: shape parameter; $F_{\mathrm{S}}$ : alignment parameter; q: shape parameter

(Orbulina sp.) and a large number of broken tests of benthic foraminifera (Ammonia sp., Globigerina sp., Elphidium sp. and sea-urchin radiols).

\section{Discussion}

New insights into the geomorphic and sedimentary signature of tsunami flooding

The Tahaddart site displays the characteristics of severe erosional signature. The upper topography of the proximal and intermediate dune has been completely eroded. This strong soil erosion allows differential erosion to occur on the top of the two dunes. Deflation and runoff, led to the formation of the surface armoring by carbonate concretions. The limit of the erosion processes action is clear and still visible in the landscape: on the distal dune, above an undulating limit, the original soil remains undisturbed. Thick layers of sandy material resulting from the dune erosion are accumulated on the dunes flanks and within the inter-dunes depressions. The scouring of the top of the Tahaddart proximal and intermediate dunes pleads for a strong energy marine flooding as attested by : $i$ ) the erosion marks left on the two dunes morphology; $i$ ) the marine origin of the sands accumulated in the topographical lows which is confirmed by the presence of marine foraminifera and numerous marine bioclasts). We assume that this marine high energy flooding that left marks far landward corresponded to a tsunami. The recognition of such patterns is important for the search of paleotsunami deposits, as evidence of truncated paleo-dunes is indicative of a large-scale wave event (e.g. Nishimura \& Miyaji 1995; Goff 2008; Goff et al. 2009; Goff et al. 2012; Dawson and Stewart 2007; Kain et al. 2014).

It is important to consider the geomorphological effects that (palaeo) storms and (palaeo) tsunamis might have had on the coastal landscape. General observations of the potential longshore and inland extent of these two processes have been discussed in recent literature (e.g. Dawson 1994, Goff et al. 2004, Goff 2008, Goff et al. 2009, Goff et al. 2012; Jaffe and Gelfenbaum 2007; Morales et al. 2011). In general terms, the longshore and inland inundation from a tsunami would, on average, be expected to be greater than that of a storm. In general terms, and based upon field evidence from 2004 IOT sites, inundation by large, region-wide events is likely to cause multiple breaching of dune systems (Higman et al. 2005; Singarasubramanian et al. 2006). In other words, multiple breaching assemblages can be formed during one inundation. The assemblages could include remnant dune ridges, or pedestals, uplift or subsidence/compaction of site/locality, scour/erosion/reworking of sediments at site/locality, altered dune morphology and sand sheet or 


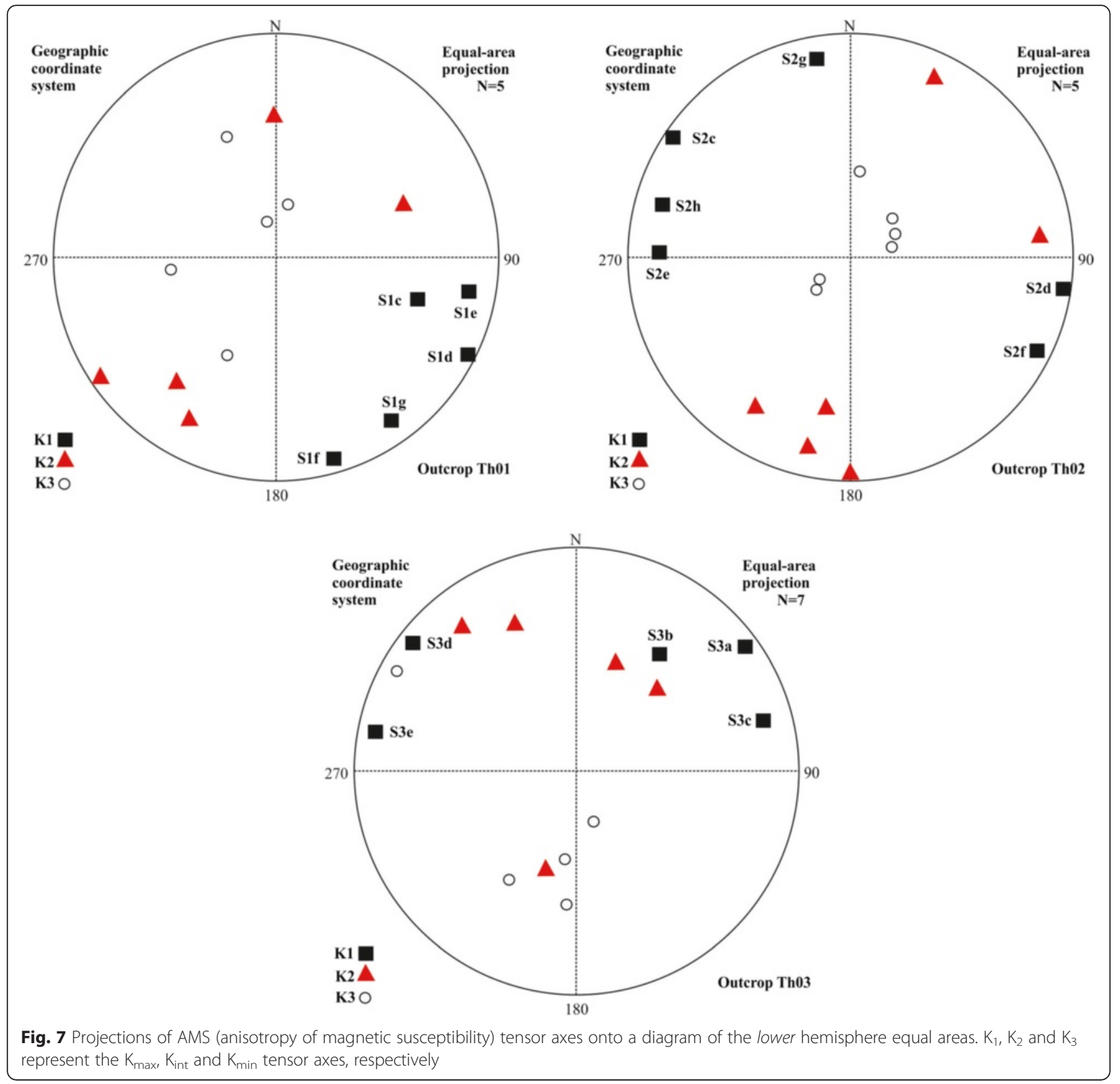

other similar deposits such as gravel deposition/gravel and carbonates pavements (Kitamura et al. 1961; Sato et al. 1995; Yulianto et al. 2007; Luque et al. 2002).

The sedimentological investigations of this study include a medium to fine sandy colluvial deposit composed of a mixture of beach-rock from marine Pleistocene terrace, beach sand, pottery microlitic industry, gastropods, shells and shell fragments of a Pleistocene lowstand beach on the shelf. Outcrop-scale diagnostic characteristics of sandy colluvium deposits shows that all grain size fractions from medium sands to clays are present. Samples are composed almost exclusively of sand (e.g. >80 \%). Grain size distributions are fine skewed.

Under the binocular microscope (bulk samples), the tsunami deposit is mostly composed of subangular to subrounded quartz grains derived from sedimentary successions of the hinterland belt (Numidian sandstones), like those sampled from the actual beach. Some grains are partially covered by an iron oxide crust, suggesting subaerial oxidation in an Aeolian environment or weathering in a soil horizon (Dorn 1998). Numerous bioclasts were identified: benthic foraminifers, marine gastropods and rare echinoderms (sea-urchin radiols). 
Tsunami deposits can be divided between uprush and backwash units, although the distinction is not always simple. The most characteristic features of uprush units are sand-sheets that cover the sub-horizontal areas (Chagué-Goff et al. 2011; Keating et al. 2011b; Goff et al. 2012). Vertical grain-size distribution within the sand layer can form graded bedding, with often coarse sand at the base and fine sand at the top (Cuven et al. 2013; Koster and Reicherter 2014). Backwash units have been recognized in inhabited areas from the presence of human artefacts in the deposits (Shi et al. 1995; Bondevik et al. 1997b; Minoura et al. 1997). The backwash often erodes the substratum and the newly deposited tsunamites before depositing a poorly sorted sandy mud or fine grain sands. Bent plants (Hori et al. 2007) indicate the direction of the backwash of a tsunami, which is not always the opposite direction of the runup (Gelfenbaum and Jaffe 2003; Hori et al. 2007; Paris et al. 2007; Wassmer et al. 2010).

The tsunami waves, train in Tahaddart deposits, generated a cycle of erosion-deposition processes, leading to the emplacement of successive fining-upwards sub-units. Normal grading is often reported for tsunami deposits (e.g. Shi et al. 1995; Bondevik et al. 1997b; Minoura et al. 1997; Gelfenbaum and Jaffe 2003), especially in their upper part, reverse graded or ungraded material is typical of the lower part of tsunami deposits but is less common than normal grading (Hori et al. 2007; Paris et al. 2007; Choowong et al. 2008). Erosion of the substratum by the tsunami flood waters is attested by scour-and-fill features and rip-up clasts (of soil for example). Rip-up clasts of clay or soil (from the substratum or mud lines) grade into stretched rip-ups, discontinuous laminae (Gutiérrez-Mas et al. 2009; Pozo et al. 2010). The abundance of rip-up clasts of organic matter decreases upwards. However, a constant problem when interpreting a tsunami sequence is the doubt due to erosion of underlying deposits by each wave within the wave train, thus truncating the record, especially if wave amplitude increases during the event (Wagner and Srisutam 2011; Higman and Bourgeois 2008; Moore et al. 2011).

The base layer of the deposited sedimentary sequence displays larges rip-up of black soil imbricated landward. These clasts were scoured and peeled away from the basal dark mud/silt level upper surface of the dark silt and stretched toward the SE, so that at their extremity, numerous micro-clasts are liberated. The upper part of the deposit shows large elongated rip-up imbricated seaward by a strong backwash channelized by the local topography. This is most probable a backwash deposit because of the mixture of coastal and offshore sediments, seaward imbricated clasts and flakes embedded within finely skewed sands and mud/gritty mud. A debris flow origin can be excepted due to the young marine components and the sedimentary features inside the deposit (e.g. Dawson and Stewart 2007; Bourgeois 2009). These tsunami deposits are similar in appearance to those found by other researchers studying tsunamis along the Golf of Cadiz (Higman and Bourgeois 2008; Moore et al. 2011; Cuven et al. 2013; Koster and Reicherter 2014).

\section{Interpretation of grain-size data and CM diagrams}

The bivariate plots (Fig. 8) confirm that the material emplaced by the marine flooding corresponds to the high-energy domain. This has been show previously for tsumani in recent studies (e.g.,Wassmer et al. 2010; Chagué-Goff et al. 2011; Szczucinski 2012). The mean grain-size versus sorting diagram (Fig. 8a) is suitable for this study for two reasons: firstly, it was applied by Lario et al. (2002) and Koster and Reicherter (2014) using samples from the same region (the Gulf of Cádiz) with a likely comparable regional setting, and secondly it includes features for fluviatile, storm and tsunami deposits. All samples cluster in the zone of fluvial and storm/tsunamis episodes. Due to their flooded marshland character, the samples from the marshlands plot in the low energy area of partially open to restricted estuary (Koster and Reicherter, 2014). The metric Steward's diagram uses a sorting vs. median plot (applied by Szczucinski (2012) on tsunami deposits). Moreover, the plotted reference samples indicate a mixture of both beach (marine) and marshland environments (Fig. 8b).

Statistical studies in fluvial and littoral environments allowed Passega $(1957,1964)$ to draw the CM diagram that relates the transport conditions of the sediment prior deposition to grain-size parameters (C99 vs. median grain size).

Although Passega (1957) suggested the first coarsest percentile as the "C" value, we used instead the C95 in our diagrams, as already proposed by Allen (1971). This choice appears pertinent to avoid the statistical effect of the presence of an abnormally coarse grain within the grain-size distribution. The values of the median and C95 parameters are extrapolated from the calculated cumulative curves for the construction of CM diagrams to correlate grain size data with transport and emplacement mechanisms (Fig. 9).

According to the CM diagrams, rolling along the ground, which corresponds to the highest energy conditions, is the transport mechanism of the coarsest sediments with the highest median and C95 values. When energy gradually decreases, the mechanisms are the graded suspension (that usually leads to normal grading during deposition) followed by uniform suspension for the transport of finer particles. The finest sediments with the lowest C95 values correspond to the conditions of pelagic suspension. Bed load transport occurs for sediments with C95 above $500 \mu \mathrm{m}$, whereas pure suspension transport occurs below this limit in weakest current conditions. As 

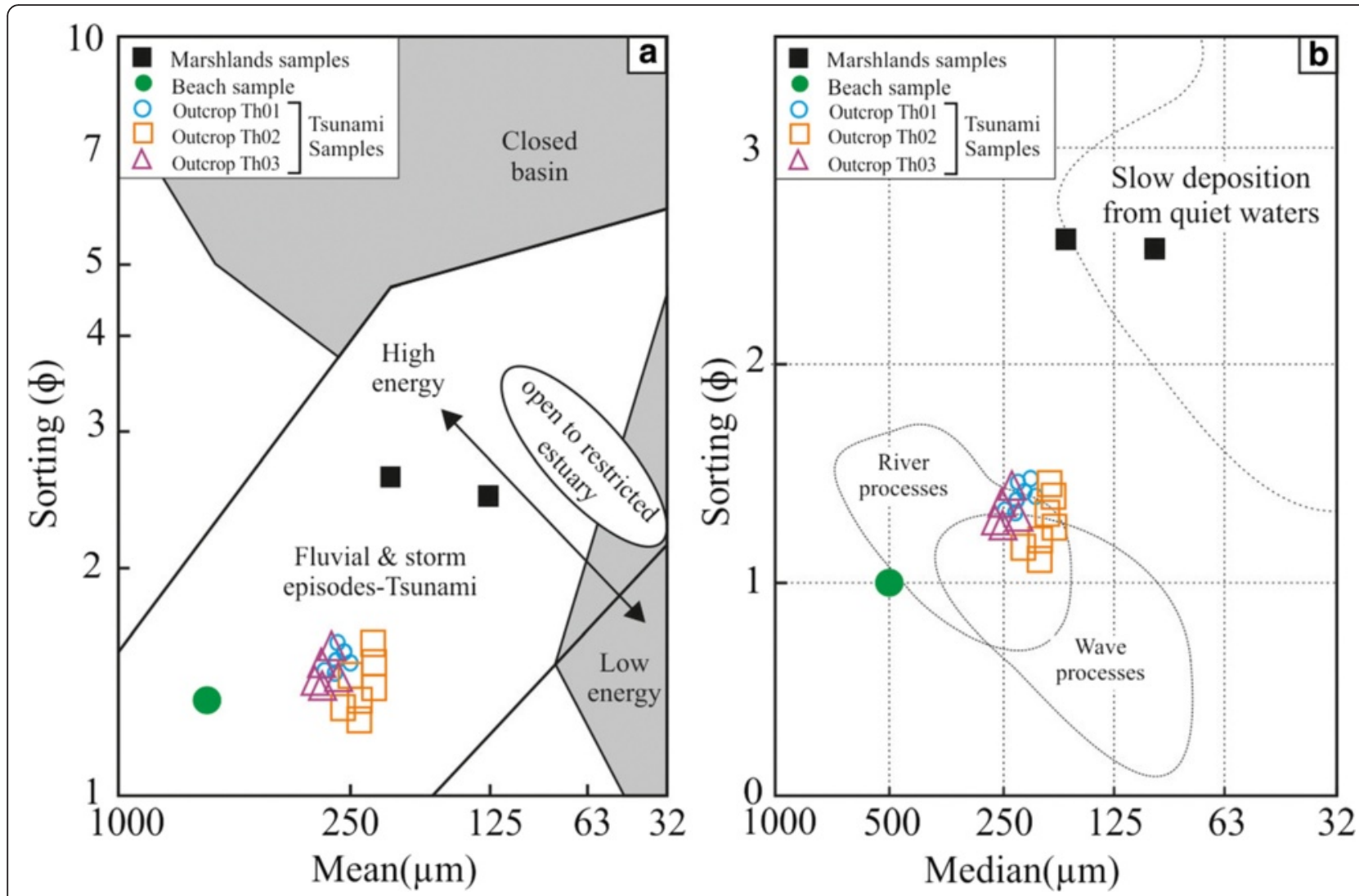

Fig. 8 a Bivariate logarithmic plot of sorting $(p h i=\Phi)$ versus mean grain size $(\mu \mathrm{m})$ after Lario et al. $(2002)$ and $\mathbf{b}$ bivariate metric plot of sorting $(\mathrm{phi}=\Phi)$ versus median grain size $(\mu \mathrm{m})$

this diagram allows the reconstruction of transport mechanisms during the sediment emplacement, it is useful to correlate the results obtained with this diagram with the ASM data to reconstruct hydrodynamic conditions during the emplacement of the tsunami deposits.
In the CM diagram samples from the tsunami unit and the reference samples from the beach are located in highenergy depositional area, while the marshland samples are located in low-energy zones (Fig. 9). Concerning the CM diagram, the tsunami samples perhaps represent a strong

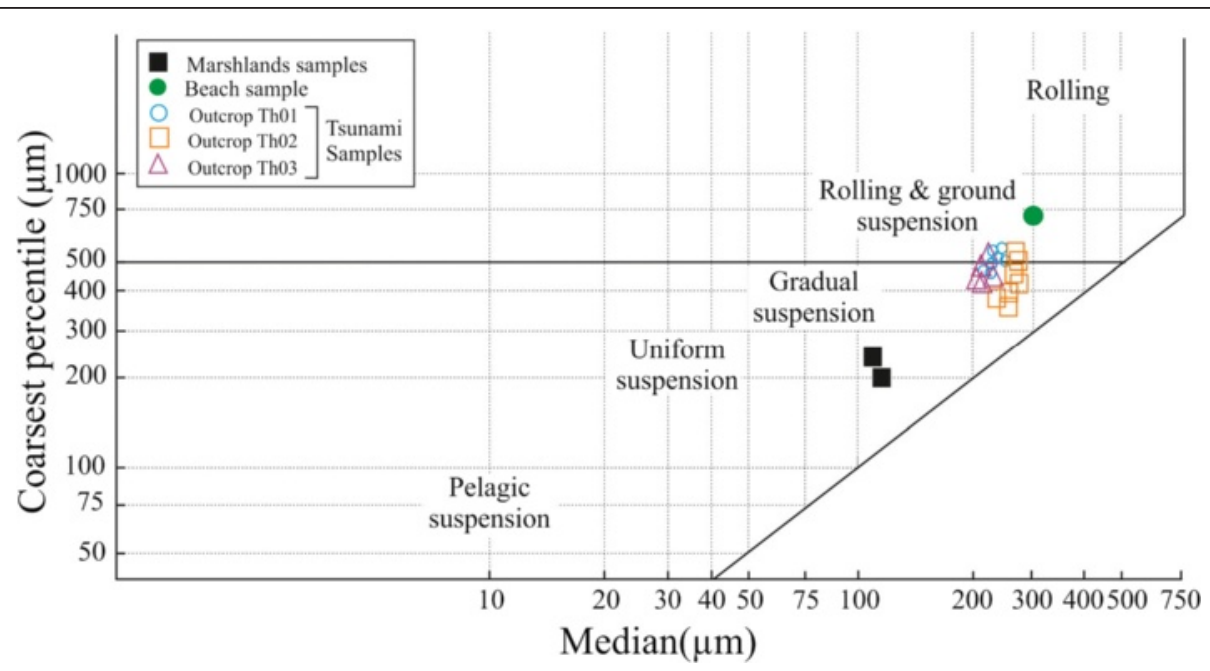

Fig. 9 CM diagram of the tsunami deposit samples along the Tahaddart lowland as well as reference samples from beach and marshland 
bottom current as tsunamis have high velocities for runup (10-20 m/s; Dawson and Stewart 2007) and backwash flow (e.g., Bryant 2008).

Important hydrodynamic fluctuations are revealed by the grain size signatures in the CM diagrams. The fluctuations of the $\mathrm{C} 95$ vs. median grain size indicate rapid change in transport mechanisms from rolling to gradual suspension during tsunami wave, but the suspension transport dominates. For each wave cycle, the energy variability in the depositional environment is important, with higher energy during the sedimentation of the basal than during the emplacement of the top of the deposit intervals, which could have been partially reworked during the tsunami shuttle inundations. For this upper part of the deposits, the gradual transport mechanisms dominate because the sediment is finer grained and the currents less energetic. Despite the fact that each wave inundated an already flooded area, sediments deposited in the breeding ponds record these fluctuations.

\section{AMS and paleocurrent reconstruction}

The projections of the AMS tensor axes onto a diagram of the lower hemisphere equal areas (Fig. 7) give information on the influence of currents on the privileged orientation of the long axes of grains. Flow direction is inferred from the plane determined by Kmax/Kint axes of the anisotropy ellipsoid. This plane reflects the characteristics (orientation and tilting) of the sediment fabric. Usually, solely the Kmax that parallels sand grains long axis is used to retrieve the sediment fabric and by then, the flow direction (Winkler et al. 1997; Wassmer et al. 2010; Wassmer and Gomez 2011).

The fabric of the material (outcrop Th01) is oriented toward the ocean from N280 at the base to N325 at the top of the sequence. It seems that the lower and the upper layers of this thick sandy sequence have been emplaced by the same processes as attested by the similarities of the included clasts. Clasts within the upper layer display imbrications conform to the direction of a flow to the NW (N100 to N164). Reverse imbrications for the clasts of the lower layer reflect undoubtedly an opposite flow, i.e. a landward flow. The presence of the numerous rip-up clasts pleads for a very high energy level that can be produced only by tsunami flooding. The sedimentary sequence begins by an uprush phase that arrived on this zone from the sector NW. The lower member of the sequence is then deposited and the ripup clasts collected between the shoreline and the sampling site were shingled and elongated by the strong current. The reverse flow or backwash emplaced then the upper member, imbricating rip-up clasts toward the sea (Fig. 5). The receding water was guided in this area by the topographic low of the laguna acting as a kind of shortcut between Oued Hachef and the mouth of Oued
Mharhar. The velocity of the water was strong enough in the near shore area to remove and transport large ripup clasts. The spreading of the backwash direction can be explained by the combination of the local topography and temporal evolution of water velocity and flow depth.

Within the outcrop Th02, the fabric of the material is oriented landward from N91 to N171. The complete sequence emplaced here appears to have been deposited by an uprush flow, the direction of which is in perfect line with the flooding orientations according to the potential tsunami sources given by Omira et al. (2011). The direction recorded by sample B (N171) is probably induced by the local topography (Fig. 7). It corresponds to a flow running down the southern slopes of the second dune. This latter layer is characterized by the lowest sorting index (Folk \& Ward) of the sequence and pleads for a well sorted sediment stock origin and the second dune could be a good candidate for this sediment source. All the other sources, pointed out by the flow directions are strictly littoral sources, i.e. the flow does not over cross the dunes before reaching the deposition area, arriving in straight line from the shoreline.

The dynamic of the outcrop Th03 is divided in two opposite processes, the lower and upper part. The origin of flow for lower samples may be: $i$ ) across the intermediate dune, $i i$ ) a side effect from a wave running along the NE side of the dunes. The upper samples indicate clearly a channelization effect.

\section{Micropaleontological signature}

The study of microfossils shows that the amount of species is moderately weak. All of these species are common in marine to brackish-hypersaline environments (Schiebel and Hemleben 2005; Koster and Reicherter 2014). The foraminifera in this zone consist of mainly shallow water species like Ammonia sp., Elphidium crispum etc (Fig. 10).

This foraminiferal assemblage is typical of sandy substrates with insignificant fine grained material and reflects a high hydrodynamic activity related to high wave energy, especially if the source was local beach and dune sand, as suggested by the lithofacies of the all studied outcrops. Most of the foraminifera in the beach reference samples and the tsunami deposit are typical of a nearshore environment. Elphidium crispum and Ammonia beccarii indicate a marine provenance of the sandy (tsunami) deposit. While Globigerina $s p$ are common in the Quaternary rocks and, consequently, are reworked. The marshland samples display an extended spectrum of species. Some of them (poorly preserved Nonion boueanum sp., Bulimina sp., Orbulina universa sp., and Sphaeroidinellopsis sp.) are reworked from Neogene sediments from the hinterland and transported into the marshlands by the Mharhar and Hachef Rivers. Through a tsunami event the 


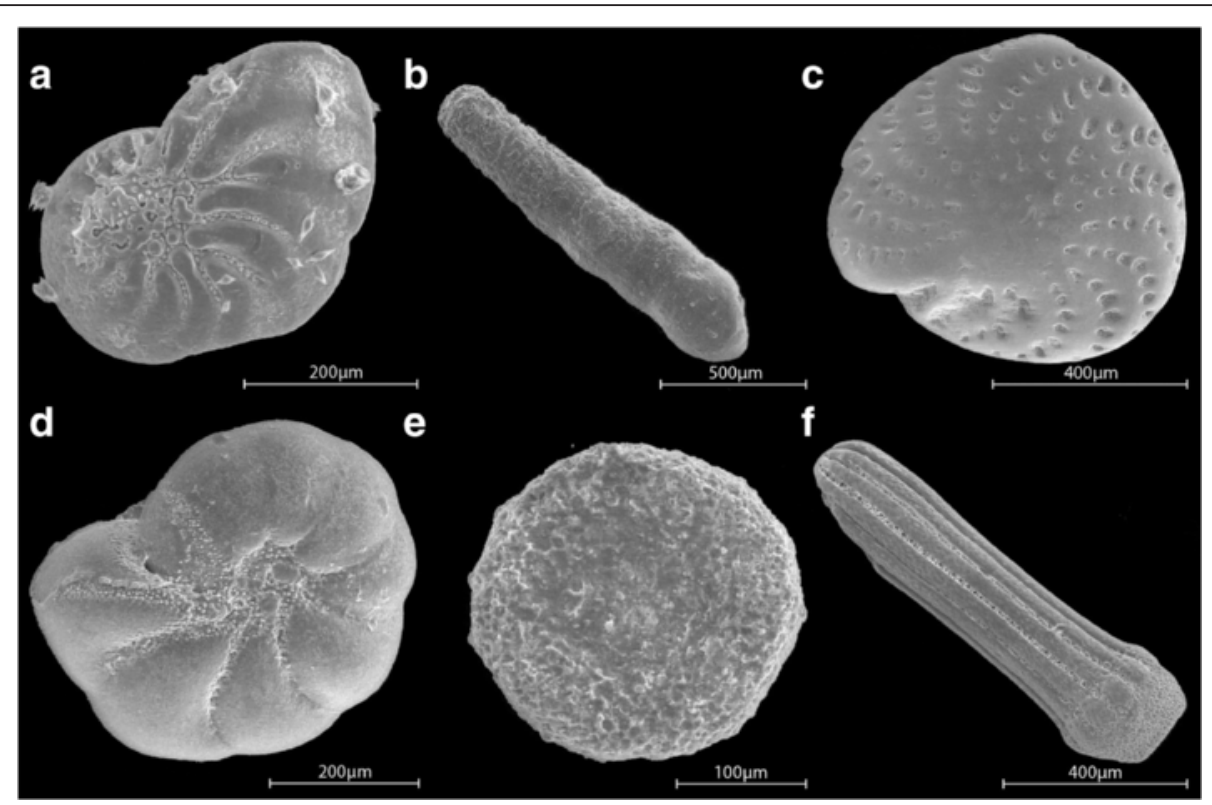

Fig. 10 Scanning electron microscope photographs of some of the selected species of foraminifera and other faunal remains from Tahaddart lowland. a Ammonia beccarii sp., b Nodosaria sp., c Elphidium crispum sp., d Elphidium leave sp., e Reworked Globigirina sp., f Fossil urchin spines

transportation of foraminifera can happen, which maybe results in broken or reworked specimens (e.g., ChaguéGoff et al. 2012). Post-tsunami processes can lead to foraminiferal damage and dissolution, either completely or partly (e.g., Mamo et al. 2009; Yawsangratt et al. 2012). Hawkes et al. (2007) also reports the lack of minor species/foraminifera (such as it was found in the marshlands) within tsunami deposits.

\section{Conclusion}

Field investigation and laboratory analysis on the Tahaddart area of Tangier-Asilah coast provide high-resolution record of a high energy marine flooding. It is most probable that remains of the AD 1755 Lisbon ancient tsunami deposit, which affected the Atlantic coast of Morocco, have been revealed, as found in further areas along the Atlantic coasts (Portugal and Spain). Sedimentological (grain size, sorting, AMS) and micropaleontological (foraminifera) analysis are combined here to provide a primary reconstruction of flow dynamics in Tahadart area. Vertical variations in sediment composition, fabric and texture of the tsunami deposits in Tahaddart area are then debated with reference to present literature on investigative criteria usually used for identifying and understanding tsunami deposits. Field observations and laboratory analyses concur to confirm a marine origin for the sedimentary deposits. The characteristics of the magnetic fabric of the deposits also allowed the reconstruction of flooding direction of the tsunami waves. Mean Kmax axes were either parallel or normal to the direction of propagation of the tsunami waves. Variations in their orientation were both related to current strengths, grain size of the deposits, and local topographic control. The presence of large imbricated rip-up as well as the AMS data (based on the Kmax) confirm that these deposits are related to a high intensity tsunami. The strong energy is also attested by the fact that the sea water over passed the first highest dune, and then the second, eroding them to the bedrock. This marked the starting point of a continuous and efficient Aeolian and runoff erosion process. This differential erosion slowed then down and was eventually stopped by the progressive formation of a surface armoring resulting of the concentration of carbonate concretions at the surface. These 8 and $6 \mathrm{~m}$ in height dunes were probably at least 1-2 $\mathrm{m}$ higher before the erosion interval initiated by the tsunami. The fresh aspect of the area morphology, i.e. dunes erosion marks, pleads for a rather recent event. AMS technique performed at the base of the deposited sequence allows retrieving the direction of the first wave which is usually not disturbed by refraction/ reflection processes when running on a flat coastal morphology. The first wave here, points out an N 105 origin but the local topography of the estuary and the field dune might have modify the original flow direction. This contribution allows confirming the occurrence of a strong energy marine flooding on the coast South of Tangier in the area of Tahaddart. The characteristics of the deposits as well as the rather fresh morphology of the dunes eroded by the waves plead in favor of a recent event. The best candidate on this part of the Moroccan Atlantic coast remains the 1755 earthquake triggered 
tsunami. The height of the dunes affected by wave erosion processes allow to estimate wave heights around 68 meters, i.e. more close to the historic values and the values estimated by Omira et al. (2012) $6 \mathrm{~m}$ and Blanc (2009) $25 \mathrm{~m}$.

\section{Acknowledgement}

We are thankful to Mrs. Martine TRAUTMANN « Laboratoire d'Analyses des Sols et des Formations Superficielle », EOST Laboratory, University of Strasbourg, for her help with all of the samples preparation and grain size analysis. The authors are indebted to two reviewers Prof. Christopher Gomez and Prof. Rachid Omira and to the Editor in Chief of the Geoenvironmental Disasters Prof. Fawu Wang for their reviews, discussions, and suggestions on the manuscript.

\section{Authors' contributions}

All of authors performed the field research. HEL conducted the experiments, analyzed the data, and wrote the first draft of the manuscript. MEL collected the data and went for field study. MNZ revised the manuscript and data analysis. KA conceived of the study and carried out the micropalaeontological analysis. PW carried out the AMS analysis and data interpretation. JLM participated in design and coordination of the study, and helped to interpret the results. All of the authors drafted, read and approved the final manuscript.

\section{Competing interests}

The authors declare that they have no competing interests.

\section{Author details}

'Department of Earth Sciences Faculty of Sciences and Techniques, University Abdelmalek Essaadi, PB. 416, 90000 Tangier, Morocco. ${ }^{2}$ Laboratoire de Géographie Physique, CNRS UMR 8591, Université Panthéon-Sorbonne (Paris 1), 1 place Aristide Briand, F-92195 Meudon, Cedex, France. ${ }^{3}$ Université de Strasbourg, Faculté de Géographie et d'Aménagement, 3 rue de l'Argonne, F-67000 Strasbourg, France.

Received: 17 February 2016 Accepted: 27 June 2016 Published online: 26 July 2016

\section{References}

Allen, G.P. 1971. Relationships between grain size parameter distribution and current patterns in the Gironde estuary (France). Journal of Sedimentary Petrology 41(1): 74-88.

Alouane M. 1986. Les formations quaternaires du littoral atlantique de la province de Tangier (Maroc). PhD Thesis. Université Bordeaux I.

Alvarez-Gómez, J.A., I. Aniel-Quiroga, M. González, and L. Otero. 2011. Tsunami hazard at the Western Mediterranean Spanish coast from seismic sources. Natural Hazards and Earth System Sciences 11: 227-240.

Baptista, M.A., Miranda, P.M.A., Miranda, J.M., Mendes Victor, L. 1992. Rupture extent of the 1755 Lisbon earthquake inferred from numerical modeling of tsunami data. Physics and Chemistry of the Earth, 21(1-2):65-70.

Baptista, M.A., S. Heitor, J.M. Miranda, P. Miranda, and L. Mendes-Victor. 1998. The 1755 Lisbon earthquake; evaluation of the tsunami parameters. Journal of Geodynamics 25: 143-157.

Baptista, M.A., and J.M. Miranda. 2009. Revision of the Portuguese catalog of tsunamis. Natural Hazards and Earth System Sciences 9: 25-42.

Baptista, M.A., J.M. Miranda, F. Chiericci, and N. Zitellini. 2003. New study of the 1755 earthquake source based on multi-channel seismic survey data and tsunami modelling. Natural Hazards and Earth System Sciences 3: 333-340.

Barkan, R., U.S. Ten Brink, and J. Lin. 2009. Far field tsunami simulations of the 1755 Lisbon earthquake: Implications for tsunami hazard to the U.S. East Coast and the Caribbean. Marine Geology 264: 109-122.

Bewick B. 1757. An account of the Earthquake at Cádiz, November 1, 1755, in: Letter from Benjamin Bewick, Merchant there, to Mr. Joseph Paice, Merchant in London, Lett. XIV, for the Year 1756, Philosophical Transactions, Vol. XLIX, Part II, London.

Blanc, P.L. 2008. The tsunami in Cadiz on 1 November 1755: A critical analysis of reports by Antonio de Ulloa and by Louis Godin. Comptes Rendus Geoscience 340: $251-261$.
Blanc, P.L. 2009. Earthquakes and tsunami in November 1755 in Morocco: a different reading of contemporaneous documentary sources. Natural Hazards and Earth System Sciences 9: 725-738.

Bondevik, S., J.I. Svendsen, and J. Mangerud. 1997b. Tsunami sedimentary facies deposited by the Storegga tsunami in shallow marine basins and coastal lakes, western Norway. Sedimentology 44: 1115-1131.

Borlase W. 1755. Letter to the Rev. Charles Lytleton, L. L. Dean of Exeter, Lett. XV, printed for L. Davis and C. Reymers, Printers to the Royal Society, against Gray's Inn Gate, in: Holbourn, for the Year 1756, Philosophical Transactions Vol. XLIX, Part II, London.

Boughaba A. 1992. Les littoraux meubles septentrionaux de la péninsule de Tanger (Maroc). Geomorphologie et effet de l'intervention anthropique sur leur environnement. PhD thesis, University of Nantes.

Bourgeois, J. 2009. Geologic effects and records of tsunamis. In The Sea: Volume 15, ed. E.N. Bernard and A.R. Robinson, 55-91. Tsunamis: Cambridge, Massachusetts: Harvard University Press.

Bridoux, V., Kbiri Alaoui, V., Biagi, S., Dridi, H., Ichkhakh, A. 2011. La mission archéologique franco-marocaine de Kouass au Maroc. Les Nouvelles de l'archéologie, 123 : 44-48.

Bryant E. 2008. Tsunami: The Underrated Hazard. Berlin, New York, Springer; Chichester, England, Published in association with Praxis, p 330.

Chagué-Goff, C. 2010. Chemical signature of palaeotsunamis: a forgotten proxy. Marine Geology 271: 67-71.

Chagué-Goff, C., A. Andrew, W. Szczucinski, J. Goff, and Y. Nishimura. 2012a. Geochemical signatures up to the maximum inundation of the 2011 Tohokuoki tsunami-implications for the $869 \mathrm{AD}$ Jogan and other palaeotsunamis. Sedimentary Geology 282: 65-77.

Chagué-Goff, C., P. Niedzielski, H.K.Y. Wong, W. Szczucinski, D. Sugawara, and J.R. Goff. 2012b. Environmental impact assessment of the 2011 Tohoku-oki tsunami on the Sendai plain. Sedimentary Geology 282: 175-187.

Chagué-Goff, C., J.L. Schneider, J.R. Goff, D. Dominey-Howes, and L. Strotz. 2011. Expanding the proxy toolkit to help identify past events-lessons from the 2004 Indian Ocean Tsunami and the 2009 South Pacific Tsunami. Earth-Science Reviews 107: 107-122.

Chambers C. 1757. Another account of the same earthquake at Madeira in a letter from Charles Chambers to his father, in London, dated at Madeira, Novem. I, 1755, Communicated by Lewis Crusius, D. D. F. R. S., Lett. XVIII, for the Year 1756, Philosophical Transactions Vol. XLIX, Part II, London.

Cherkaoui, T.E., and A. El Hassani. 2012. Seismicity and seismic hazard in Morocco 1901-2010. Bulletin de I'Institut Scientifique, Rabat, section Sciences de la Terre 34: 45-55.

Choowong, M., N. Murakoshi, K. Hisada, P. Charusiri, T. Charoentitirat, V. Chutakositkanon, K. Jankaew, P. Kanjanapayont, and S. Phantuwongraj. 2008. 2004 Indian Ocean tsunami infow and outfow at Phuket, Thailand. Marine Geology 248: 179-192.

Costa, P.J.M., C. Andrade, M.C. Freitas, M.A. Oliveira, V. Lopes, A.G. Dawson, J. Moreno, F. Fatela, and J.M. Jouanneau. 2012. A tsunami record in the sedimentary archive of the central Algarve coast, Portugal: characterizing sediment, reconstructing sources and inundation paths. The Holocene 22(8): 899-914.

Cuven, S., R. Paris, S. Falvard, E. Miot-Noirault, M. Benbakkar, J.L. Schneider, and I. Billy. 2013. High-resolution analysis of a tsunami deposit: Case-study from the 1755 Lisbon tsunami in southwestern Spain. Marine Geology 337: 98-111.

Dawson, A.G. 1994. Geomorphological effects of tsunami runup and backwash. Geomorphology 10: 83-94.

Dawson, A.G., and I. Stewart. 2007. Tsunami deposits in the geological record. Sedimentary Geology 200: 166-183.

Dorn, R.I. 1998. Rock coatings, Vol 6, 429. Amsterdam: Elsevier.

Durand-Delga, M., and J. Komprobst. 1985. Carte géologique de Tanger-Al Manzla (1 /50000), 294. Rabat: Notes et Mémoires du Service Géologique du Maroc.

El Idrissi A. 2012. Le Néolithique du Maroc: Etat de la question. Congrés Internacional Xarxes al Neolític: Neolithic Networks. Rubricatum. Revista del Museu de Gavà, 5: 1135-3791

El Alami, S.O., and S. Tinti. 1991. A preliminary evaluation of the hazards in the Moroccan coasts. Science of Tsunami Hazards 9(1): 31-38.

El Mrabet, A.T. 2005. The great earthquakes in the Maghreb region and their consequences on man and environment. Rabat: CNRST-LAG.

Fowke Th. 1756. An account of the earthquake in Barbary, inclosed in a letter from General Fowke, Governor of Gibraltar, to the Right Honourable Henry Fox, Philosophical Transactions, Vol. XLIX, part I, London.

Gelfenbaum, G., and B.E. Jaffe. 2003. Erosion and sedimentation from the $17 \mathrm{July}$, 1998 Papua New Guinea Tsunami. Pure and Applied Geophysics 160: 1969-1999. 
Genet P. 2011. Signature sédimentaire des tsunamis sur la côte atlantique marocaine entre Tanger et Larache et implications en terme de risque. Mémoire master 1. Université Blaise Pascal Clermont-Ferrand.

Godin, L. 1755. Sur le Tremblement de Terre qui s'est fait sentir à Cadix le 1er novembre 1755 (lu par Bouguer) P.-V. Royal Academy of Sciences of Paris 74: 772-781.

Goff, J.R., A. Wells, C. Chagué-Goff, S.L. Nichol, and R.J.N. Devoy. 2004. The elusive AD 1826 tsunami, South Westland, New Zealand. New Zealand Geographer 60(2): $28-39$.

Goff, J.R. 2008. The New Zealand palaeotsunami database, NIWA Technical Report 131. Christchurch, New Zealand: National Institute of Water \& Atmospheric Research.

Goff, J.R., E. Lane, and J. Arnold. 2009. The tsunami geomorphology of coastal dunes. Natural Hazards and Earth System Sciences 9: 847-854.

Goff, J.R., C. Chagué-Goff, S.L. Nichol, B. Jaffe, and D. Dominey-Howes. 2012. Progress in palaeotsunami research. Sedimentary Geology 243-244: 70-88. doi:10.1016/j.sedgeo.2011.11.002.

Gràcia, E., J. Dañobeitia, J. Vergés, and P. Team. 2003. Mapping Active Faults Offshore Portugal $\left(36^{\circ} \mathrm{N}-38^{\circ} \mathrm{N}\right)$ : Implications for Seismic Hazard Assessment Along the Southwest Iberian Margin. Geology 31(1): 83-86.

Gutiérrez-Mas, J.M., C. Juan, and J.A. Morales. 2009. Evidence of high-energy events in shelly layers interbedded in coastal Holocene sands in Cadiz Bay (south-west Spain). Earth Surface Processes and Landforms 34: 810-823.

Gutscher, M.A., Malod, J., Rehault, J.P., Contrucci, I., Klinghoefer, F., Mendes-Victor, L., Spakman, W. 2002. Evidence for active subduction beneath Gibraltar. Geology 30: 1071-1074

Gutscher, M.A., M.A. Baptista, and J.M. Miranda. 2006. The Gibraltar Arc seismogenic zone (part 2): constraints on a shallow east dipping fault plane source for the 1755 Lisbon earthquake provided by tsunami modelling and seismic intensity. Tectonophysics 426: 153-166. doi:10.1016/j.tecto.2006.02.025.

Harbitz, C.B., S. Glimsdal, S. Bazin, N. Zamora, F. Løvholt, H. Bungum, H. Smebye, P. Gauer, and O. Kjekstad. 2012. Tsunami hazard in the Caribbean: Regional exposure derived from credible worst case scenarios. Continental Shelf Research 8: 1-23.

Hawkes, A.D., M. Bird, S. Cowie, C. Grundy-Warr, B.P. Horton, A.T. Shau Hwai, L. Law, C. Macgregor, J. Nott, J.E. Ong, J. Rigg, R. Robinson, M. Tan-Mullins, T.T. Sa, Z. Yasin, and L.W. Aik. 2007. Sediments deposited by the 2004 Indian Ocean Tsunami along the Malaysia-Thailand Peninsula. Marine Geology 242: 169-190.

Hayward, B.W., M. Holzmann, H.R. Grenfell, J. Pawlowski, and C.M. Triggs. 2004. Morphological distinction of molecular types in Ammonia-towards a taxonomic revision of the world's most commonly misidentified foraminifera. Marine Micropaleontology 50: 237-271.

Higman, B., and J. Bourgeois. 2008. Deposits of the 1992 Nicaragua tsunami. In: Shiki, T., Tsuji, Y., Yamazaki, T., Minoura, K. (Ed), Tsunamites Features and Implications. Elsevier, pp. 81-103.

Higman, B., P. Lynett, B. McAdoo, J. Borrero, and P. Ruggiero. 2005. Geomorphic imprint of the 2004 Sumatra tsunami, GSA Annual Meeting, Geological Society of America Abstracts with Programs 37: 93.

Hindson, R.A., C. Andrade, and A.G. Dawson. 1996. Sedimentary processes associated with the tsunami generated by the 1755 Lisbon earthquake on the Algarve coast, Portugal. Physics and Chemistry of the Earth 21(1-2): 57-63.

Hori, K., R. Kuzumoto, D. Hirouchi, M. Umitsu, N. Janjirawuttikul, and B. Patanakanog. 2007. Horizontal and vertical variations of 2004 Indian tsunami deposits: an example of two transects along the western coast of Thailand. Marine Geology 239: 163-172.

Horton, B.P., and R.J. Edwards. 2006. Quantifying Holocene sea level change using intertidal foraminifera: lessons from the British Isles. Journal of Foraminiferal Research, Special Publication 40: 97.

Jaaidi, E.B., M. Ahmamou, R. Zougary, B. Chatre, B. El Moutchou, F. Malek, and K. Naim. 1993. Le littoral méditerranéen entre Tétouan et Ceuta et atlantique entre Tanger et Asilah. Impact des aménagements portuaires sur la dynamique côtière: cas des ports de M'diq, Restinga-Smir, Tanger et Asilah. Publication du Comité National de Géographie du Maroc, 21-33.

Jaffe, B.E., and G. Gelfenbaum. 2007. A simple model for calculating tsunami flow speed from tsunami deposits. Sedimentary Geology 200: 347-361.

Jagodziński, R., B. Sterna, W. Szczuciński, C. Chagué-Goff, and D. Sugawara. 2012. Heavy minerals in the 2011 Tohoku-oki tsunami deposits-insights into sediment sources and hydrodynamics. Sedimentary Geology 282: 57-64.

Johnston, A. 1996. Seismic moment assessment of earthquakes in stable continental regions. New Madrid, 1811-1812, Charleston 1886 and Lisbon 1755. Geophysical Journal International 126: 314-344.
Kaabouben, F., A. Baptista, A. Iben Brahim, A. El Mouraouah, and A. Toto. 2009. On the Moroccan tsunami catalogue. Natural Hazards and Earth System Sciences 9: 1227-1236.

Kain, C., C. Gomez, P. Wassmer, F. Lavigne, and H. Hart. 2014. Truncated dunes as evidence of the 2004 tsunami in North Sumatra and environmental recovery post-tsunami. New Zealand Geographer 70: 165-178.

Keating, B.H., C.E. Helsley, M. Wanink, and D. Walker. 2011. Tsunami Deposit Research: Fidelity of the Tsunami Record, Ephermal Nature, Tsunami Deposit Characteristics, Remobilization of Sediment by Later Waves, and Boulder Movements, In: Mörner, N.A. (Ed) the Tsunami Threat Research and Technology, Intech, pp 389-422

Keating, B.H., C.E. Helsley, M. Wanink, and D. Walker. 2011. Tsunami deposit research: "delity of the tsunami record, ephemeral nature, tsunami deposits characteristics, remobilization of sediments by later waves, and boulder movement. In: Mörner, N.A. (Ed) the Tsunami Threat Research and Technology. InTech, pp 389-4224.

Kitamura, N., T. Kotaka, and J. Kataoka. 1961. Ofunato-Shizugawa chiku [region between Ofunato and Shizugawa], in: Geological observations of the Sanriku coastal region damaged by tsunami due to the Chile earthquake in 1960, Contributions of the Institute of Geology and Paleontology of Tohoku University 52: 28-40.

Kortekaas, S., and A.G. Dawson. 2007. Distinguishing tsunami and stormdeposits: an example from Martinhal, SW Portugal. Sedimentary Geology 200: 208-221.

Koster, B., and K. Reicherter. 2014. Sedimentological and geophysical properties of a ca. 4000 year old tsunami deposit in southern Spain. Sedimentary Geology 314: 1-16

Lario, J., C. Spencer, A. Plater, C. Zazo, J. Goy, and C. Dabrio. 2002. Particle size characterization of Holocene back-barrier sequences from North Atlantic coasts (SW Spain and SE England). Geomorphology 42: 25-42.

Loeblich, A.R., and H. Tappan. 1988. Foraminiferal Genera and Their Classification, 2114. New York: Van Nostrand Reinhold.

Luque, L., J. Lario, J. Civis, P.G. Silva, C. Zazo, J.L. Goy, and C.J. Dabrio. 2002. Sedimentary record of a tsunami during Roman times, Bay of Cadiz, Spain. Journal of Quaternary Science 17(5-6): 623-631.

Mamo, B., L.C. Strotz, and D. Dominey-Howes. 2009. Tsunami sediments and their foraminiferal assemblages. Earth-Science Reviews 96: 263-278.

Matias, L., A. Ribeiro, M.A. Baptista, N. Zitellini, J. Cabral, P. Terrinha, P. Teves-Costa, and J.M. Miranda. 2005. Comment on "Lisbon 1755: A Case of Triggered Onshore Rupture?" by Susana P. Vilanova, Catarina F. Nunes, and Joao F. B. D. Fonseca. Bulletin of the Seismological Society of America 95 (6): 25342538.

Medina, F., Mhammdi, N., Chiguer, A.; Akil, M. and Jaaidi, E.B. 2010. The Rabat and Larache boulder fields; new examples of high-energy deposits related to extreme waves in north- western Morocco. Natural Hazards 59: 725-747.

Mellas, S., F. Leone, R. Omira, M. Gherardl, M.A. Baptista, B. Zourarah, M. Péroche, and E. Lagahé. 2012. Le risque tsunamique au Maroc : modélisation et évaluation au moyen d'un premier jeu d'indicateurs d'exposition du littoral atlantique. Physio-Géographie Physique et Environnement (VI): 119-139.

Mendonça, J.M. 1758. Historia Universal dos Terramotos que tem havido no mundo de que há noticia desde a sua criaçao até ao seculo presente, 272. Portugal: Biblioteca Nacional de Lisboa.

Minoura, K., F. Imamura, T. Takahashi, and N. Shuto. 1997. Sequence of sedimentation processes caused by the 1992 Flores tsunami: evidence from Babi Island. Geology 25(6): 523-526.

Mhammdi, N., Medina, F., Kelletat, D., Ahmamou, M., Aloussi, L. 2008. Large boulders along the Rabat coast (Morocco); possible emplacement by the November 1st, 1755 AD tsunami. Science of Tsunami Hazards 27(1):17-30.

Mhammdi, N., Medina, F., Trentesaux, A., Font, E., Belkhayat, Z., Geawhari, M.A. 2015. Sedimentary evidence of palaeo-tsunami deposits along the Loukkos estuary (Moroccan Atlantic coast). Journal of Tsunami Society International 34, 2: 15-20.

Moore, A., J. Goff, B.G. McAdoo, H.M. Fritz, A. Gusman, N. Kalligeris, K. Kalsum, A. Susanto, D. Suteja, and C.E. Synolakis. 2011. Sedimentary deposits from the 17 July 2006 Western Java tsunami, Indonesia: use of grain size analyses to assess tsunami low depth, speed, and traction carpet characteristics. Pure and Applied Geophysics 167(11): 1951-1961.

Morales, J.A., Mas J.M. Gutiérrez, J. Borrego, and A. Rodríguez-Ramírez. 2011. Sedimentary characteristics of the Holocene tsunamigenic deposits in the coastal systems of the Cadiz Gulf (Spain). In: Mörner, N.A. (Ed.), The Tsunami Threat Research and Technology. InTech, pp 237-258.

Müller, C. 1855. Geographi Graeci minores, i. Paris: Firmin Didot, 56-67.

Otte, M., and J.E. Abdellaoui. 2004. Découverte d'une sépulture néolithique: Taher. In : La Préhistoire de Tanger (Maroc), ERAUL 105, Liège, pp 169. 
Nishimura, Y., and N. Miyaji. 1995. Tsunami deposits from the 1993 Southwest Hokkaido earthquake and the 1640 Hokkaido Komagate eruption, northern Japan. Pure and Applied Geophysics 144(3/4): 719-733.

Omira, R., Baptista, M.A., Matias, L., Miranda, J.M., Catita, C., Carrilho, F., Toto, E. 2009. Design of a Sea-level Tsunami Detection Network for the Gulf of Cadiz. Natural Hazards and Earth System Science 9(4):1327-1338.

Omira, R., Baptista, M.A., Miranda, J.M., Toto, E., Catita, C., Catalão, J. 2010. Tsunami vulnerability assessment of Casablanca-Morocco using numerical modelling and GIS tools. Natural Hazards 54 : 75-95.

Omira, R., M.A. Baptista, and J.M. Miranda. 2011. Evaluating tsunami impact on the Gulf of Cadiz coast (Northeast Atlantic). Pure and Applied Geophysics 168: 1033-1043.

Omira, R., M.A. Baptista, S. Mellas, F. Leone, N. De Richemond, B. Zourarah, and J.P. Cherel. 2012. The November 1st, 1755 tsunami in Morocco: Can numerical modeling clarify the uncertainties of historical reports? In: Gloria IL (ed) Tsunami - Analysis of a Hazard - From Physical Interpretation to Human Impact. InTech, 61-76.

Omira, R., Baptista, M.A., Leone, F., Matias, L., Mellas, S., Zourarah, B., Miranda, J.M., Carrilho, F., Cherel, J.P. 2013. Performance of coastal sea-defense infrastructure at El Jadida (Morocco) against tsunami threat: lessons learned from the Japanese 11 March 2011 tsunami. Natural Hazards and Earth System Sciences 13: 1779-1794.

Paris, R., M. Cachão, J. Fournier, and O. Voldoire. 2010. Nannoliths abundance and distribution in tsunami deposits: example from the December 26, 2004 tsunami Lhok Nga (northwest Sumatra, Indonesia). Géomorphologie: Relief, Processus, Environnement 1: 109-118.

Paris, R., F. Lavigne, P. Wassmer, and J. Sartohadi. 2007. Coastal sedimentation associated with the December 26, 2004 tsunami in Lhok Nga, West Banda Aceh (Sumatra, Indonesia). Marine Geology 238: 93-106.

Passega, R. 1957. Texture as characteristic of clastic deposition. American Association of Petroleum Geologists Bulletin 41: 1952-1984.

Passega, R. 1964. Grain size representation by CM patterns as a geological tool. Journal of Sedimentary Petrology 34(4): 830-847.

Pozo, M., F. Ruiz, M.I. Carretero, J.R. Vidal, L.M. Caceres, M. Abad, and M.L. Gonzalez-Regalado. 2010. Mineralogical assemblages, geochemistry and fossil associations of Pleistocene-Holocene complex siliciclastic deposits from the Southwestern Donana National Park (SW Spain): a palaeoenvironmental approach. Sedimentary Geology 225(1-2): 1-18.

Reinson, G.E. 1992. Transgressive barrier island and estuarine systems. In: Walker, R.G., James, N.P. (Eds.), Facies Models: Response to Sea Level Change. Geological Association of Canada, St. John's 1: 179-194.

Rodríguez-Vidal, J., F. Ruiz, L.M. Cáceres, M. Abad, M.L. González-Regalado, M. Pozo, M.I. Carretero, A.M. Monge, and F. Gómez. 2011. Geomarkers of the 218-209 BC Atlantic tsunami in the Roman Lacus Ligustinus (SW Spain): a palaeogeographical approach. Quaternary International 242: 201-212.

Ruiz, C., Dietler, M. 2009. Colonial Encounters in Ancient Iberia: Phoenician, Greek, and Indigenous Relations. Chicago: University of Chicago Press, 95-100.

Sahal, A., J. Roger, S. Allgeyer, B. Lemaire, H. Hebert, F. Schindele, and F. Lavigne. 2009. The tsunami triggered by the 21 May 2003 Boumerdes-Zemmouri (Algeria) earthquake: field investigations on the French Mediterranean coast and tsunami modelling. Natural Hazards and Earth System Sciences 9: 1823-1834

Sato, H., T. Shimamoto, A. Tsutsumi, and E. Kawamoto. 1995. Onshore Tsunami Deposits Caused by the 1993 Southwest Hokkaido and 1983 Japan Sea Earthquakes. Pure and Applied Geophysics 144: 693-717.

Schiebel, R., and C. Hemleben. 2005. Modern planktic foraminifera. Paläontologische Zeitschrift 79: 135-148.

Singarasubramanian, S.R., M.V. Mukesh, K. Manoharan, S. Murugan, D. Bakkairaj, and A.J. Peter. 2006. Sediment characteristics of the M 9 tsunami event between Rameswaram and Thoothukudi, Gulf of Mannar, southeast coast of India. Sciences of Tsunami Hazards 25(3): 160-172.

Shi, S., Dawson, A.G., Smith, D.E. 1995. Coastal sedimentation associated with the December 12th, 1992 Tsunami in Flores, Indonesia. Pure and Applied Geophysics 144: 525-536.

Szczucinski, W. 2012. The post-depositional changes of the onshore 2004 tsunami deposits on the Andaman Sea coast of Thailand. Natural Hazards 60, 115-133. Shi, S., Dawson, A.G., Smith, D.E., 1995. Coastal sedimentation associated with the December $12^{\text {th }}, 1992$ tsunami in Flores, Indonesia. Pure and Applied Geophysics 144: 525-536

Wagner, J.F., and C. Srisutam. 2011. Grain-size and thin section characteristics of tsunami sediments from Thai-Andaman Coast, Thailand. In: Mörner, N.A. (Ed), The Tsunami Threat Research and Technology. InTech, pp 259-282.
Ward, S., and S. Day. 2001. Cumbre Vieja Volcano - Potential collapse and tsunami at La Palma, Canary Islands. Geophysical Research Letters 28(17): 3397-3400.

Wassmer, P., and C. Gomez. 2011. Development of the AMS Method for Unconsolidated Sediments, Application to Tsunami deposits. Geomorphologie, Relief, Processus et Environnement 3: 279-290.

Wassmer, P., J.L. Schneider, A.V. Fonfrège, F. Lavigne, R. Paris, and G. Gomez. 2010 Use of anisotropy of magnetic susceptibility (AMS) in the study of tsunami deposits: application to the 2004 deposits on the eastern coast of Banda Aceh, North Sumatra, Indonesia. Marine Geology 275: 255-272.

Winkler, A., L. Alfonsi, F. Florindo, L. Sagnotti, and F. Speranea. 1997. The magnetic anisotropy of rocks: principles, techniques and geodynamic applications in the Italian peninsula. Annali di Geofisica XL(3): 729-740.

Yawsangratt, S., W. Szczuciński, N. Chaimanee, S. Chatprasert, W. Majewski, and S. Lorenc. 2012. Evidence of probable paleotsunami deposits on Kho Khao Island, Phang Nga Province Thailand. Natural Hazards 63: 151-163.

Yulianto, E., A.L. Prendergast, K. Jankaew, A.A. Eipert, B.F. Atwater, M. Cisternas, S. Fernando, and I. Tejakusuma. 2007. Tsunami scour-fan deposits in southcentral Chile, XVII INQUA Congress Abstract 0955. Quaternary International 469: 167-168.

Zitellini, N., F. Chierici, R. Sartori, and L. Torelli. 1999. The tectonic source of the 1755 Lisbon Earthquake, Annalii Geofisica,42 (1): 49-55.

\section{Submit your manuscript to a SpringerOpen ${ }^{\mathcal{O}}$ journal and benefit from:}

- Convenient online submission

- Rigorous peer review

- Immediate publication on acceptance

- Open access: articles freely available online

- High visibility within the field

- Retaining the copyright to your article

Submit your next manuscript at springeropen.com 